\title{
Wave- and tidally-driven flow and sediment flux across a fringing coral reef: Southern Molokai, Hawaii
}

\author{
C.D. Storlazzi ${ }^{\mathrm{a}, *}$, A.S. Ogston ${ }^{\mathrm{b}}$, M.H. Bothner ${ }^{\mathrm{c}}$, M.E. Field ${ }^{\mathrm{a}}$, M.K. Presto ${ }^{\mathrm{b}}$ \\ ${ }^{a}$ US Geological Survey, Pacific Science Center, 1156 High Street, Santa Cruz, CA 95064, USA \\ ${ }^{\mathrm{b}}$ University of Washington, School of Oceanography, Box 357940, Seattle, WA 98195, USA \\ ${ }^{\mathrm{c}}$ US Geological Survey, Woods Hole Field Center, 384 Woods Hole Road, Woods Hole, MA, USA
}

Received 20 June 2003; received in revised form 7 January 2004; accepted 20 February 2004

\begin{abstract}
The fringing coral reef off the south coast of Molokai, Hawaii is currently being studied as part of a US Geological Survey (USGS) multi-disciplinary project that focuses on geologic and oceanographic processes that affect coral reef systems. For this investigation, four instrument packages were deployed across the fringing coral reef during the summer of 2001 to understand the processes governing fine-grained terrestrial sediment suspension on the shallow reef flat $(h=1 \mathrm{~m})$ and its advection across the reef crest and onto the deeper fore reef. The time-series measurements suggest the following conceptual model of water and fine-grained sediment transport across the reef: Relatively cool, clear water flows up onto the reef flat during flooding tides. At high tide, more deep-water wave energy is able to propagate onto the reef flat and larger Trade wind-driven waves can develop on the reef flat, thereby increasing sediment suspension. Trade wind-driven surface currents and wave breaking at the reef crest cause setup of water on the reef flat, further increasing the water depth and enhancing the development of depth-limited waves and sediment suspension. As the tide ebbs, the water and associated suspended sediment on the reef flat drains off the reef flat and is advected offshore and to the west by Trade wind- and tidally-driven currents. Observations on the fore reef show relatively high turbidity throughout the water column during the ebb tide. It therefore appears that high suspended sediment concentrations on the deeper fore reef, where active coral growth is at a maximum, are dynamically linked to processes on the muddy, shallow reef flat.
\end{abstract}

Published by Elsevier Ltd.

Keywords: Coral reefs; Waves; Tides; Suspended sediment; Sediment flux; Cross-shore transport

\section{Introduction}

Coral reefs typically grow in relatively clear waters. Land use practices such as overgrazing and

\footnotetext{
*Corresponding author. Tel.: +1-831-459-3428; fax: +1831-427-4748.

E-mail addresses: cstorlazzi@usgs.gov (C.D. Storlazzi), ogston@ocean.washington.edu (A.S. Ogston), mbothner@usgs.gov (M.H. Bothner),mfield@usgs.gov (M.E. Field), kpresto@ocean.washington.edu (M.K. Presto).
}

coastal development can increase the supply of sediment to the nearshore where most coral reefs develop, creating a situation of stress or even killing corals (Acevedo et al., 1989; Fortes, 2000; Rogers, 1990; Buddemeir and Hopley, 1988). High suspended sediment concentrations can attenuate photosynthetically available radiation (PAR), which in turn reduces coral growth rates (Dodge et al., 1974; Dodge and Vaisnys, 1977; Hubbard and Scature, 1985; Edmunds and Spencer-Davies, 
1989), decreases net productivity (Rogers, 1979; Edmunds and Spencer-Davies, 1989), and induces coral stress (van Katwijk et al., 1993). Suspended sediment can also be a vector for the introduction of nutrients, toxic substances and heavy metals to reefs that can stress or kill corals (Dickson et al., 1987; Souter et al., 1993; Bastidas et al., 1999). Under conditions that permit sediment accumulation, corals can be additionally stressed due to the diversion of energy required to remove sediment particles, sites for new coral recruitment can be eliminated and coral colonies can be buried (e.g. Rogers, 1990).

As discussed by Marszalek (1981), Rogers (1990), Larcombe et al. (1995, 1996), and Ogston et al. (in press), issues such as the frequency and duration of suspension events and sediment type must be evaluated to determine the impact of sediment on coral reef health. There have been a number of studies investigating currents on and wave transformation across atolls (Tartinville and Rancher, 2000), semi-enclosed bays (Kraines et al., 1998), and barrier or fringing reefs (Roberts et al., 1977, 1980; Lugo-Fernandez et al., 1998). There have been limited investigations, however, of these physical processes' control on the timing and magnitude of sediment suspension, transport and deposition on fringing coral reefs.

The fringing reef off the south coast of Molokai, Hawaii is currently being studied as part of a US Geological Survey (USGS) multi-disciplinary project that focuses on the health and geologic variability of coral reef systems. As part of these studies, a benthic boundary layer tripod ("REEFPROBE-1") was maintained midway across the shallow reef flat off Kamiloloa for 2 years to investigate flow and fine-grained terrestrial sediment resuspension (Ogston et al., in press). Results from their study indicated that net water and fine-grained terrestrial sediment flux at the instrument location was offshore and downcoast to the southwest. While the majority of the fore reef off southern Molokai has the highest percentage of live coral cover anywhere in the state (80-90\%; Jokiel et al., 2001), the region off Kamiloloa is severely degraded and displays the lowest live coral cover in the state $(>10 \%)$. A high percentage of sediment and algae cover the fore reef off Kamiloloa and are indicative of eutrophic conditions. The net offshore and downcoast water and fine-grained sediment flux measured at the REEFPROBE-1 site on the reef flat was oriented towards this degraded section of the fore reef.

Our goal here is to investigate across-reef transport processes on the fringing reef off Kamiloloa, Molokai, Hawaii. An experiment was carried out that had as its main goal to understand the processes governing fine-grained sediment suspension on the reef flat and its suspected advection across a fringing coral reef. Instruments were deployed at four stations to better understand the nature of fluid flow and sediment suspension across the reef. These observations elucidate the complex interactions between waves, tides, and mean currents that drive fine-grained terrestrial sediment suspension on the reef flat and its advection out over the reef crest and onto the depauperate section of the fore reef.

\section{Study area}

\subsection{Molokai Reef tract}

The island of Molokai is located roughly $21^{\circ} \mathrm{N}$, $157^{\circ} \mathrm{W}$ in the North-central Pacific between the islands of Oahu and Maui in the Hawaiian Archipelago (Fig. 1). The island is $62 \mathrm{~km}$ long east-west and on average $13 \mathrm{~km}$ wide north-south and is comprised of two basaltic shield volcanoes formed roughly 1.90-1.76 m.y.a. (Clague and Dalrymple, 1989); the east Molokai volcano is $1515 \mathrm{~m}$ high and the west Molokai volcano is $420 \mathrm{~m}$ high. A $53 \mathrm{~km}$ long fringing coral reef lies off the south shore of the island in the Kalohi and Pailolo Channels between Molokai, Lanai, and Maui. The ancestral reef pinches out roughly $7 \mathrm{~km}$ from the west end of the island and $3 \mathrm{~km}$ from the east end of the island. The reef flat, a roughly horizontal surface with water depths ranging from $0.3-2.0 \mathrm{~m}$, extends from the shoreline up to $1.5 \mathrm{~km}$ offshore.

Calcareous marine sediment dominates the coarse-grained fraction of the bed sediment 


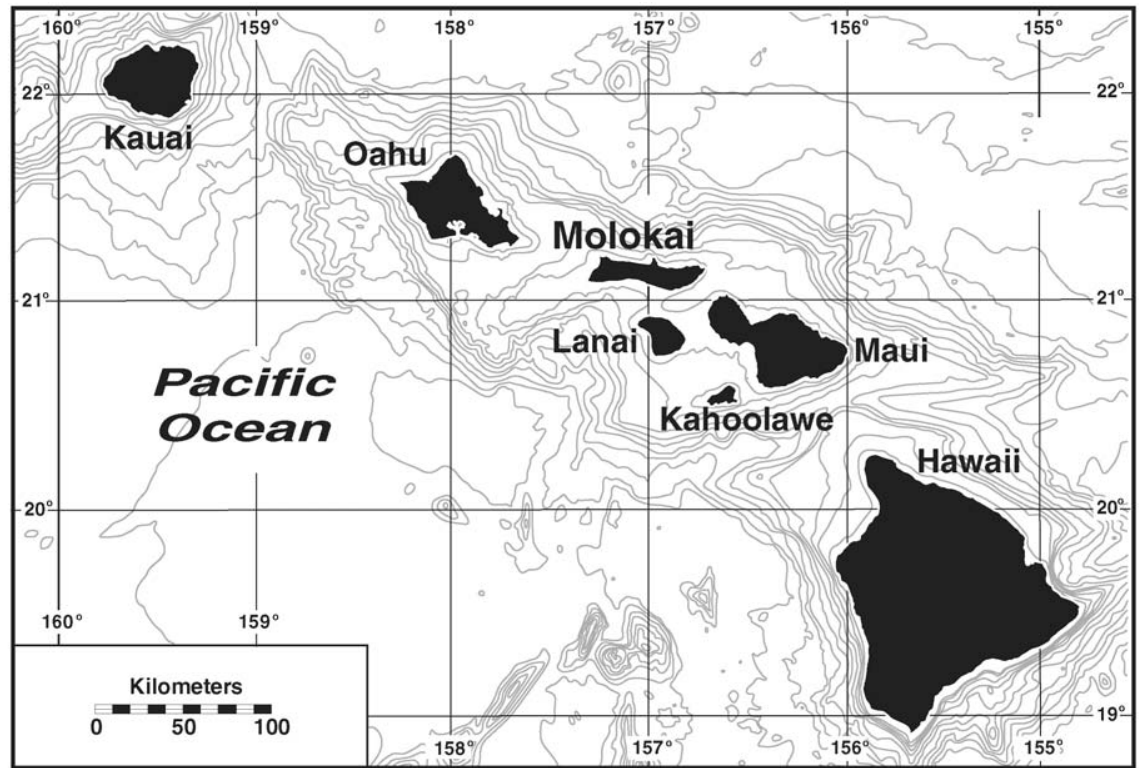

(a)

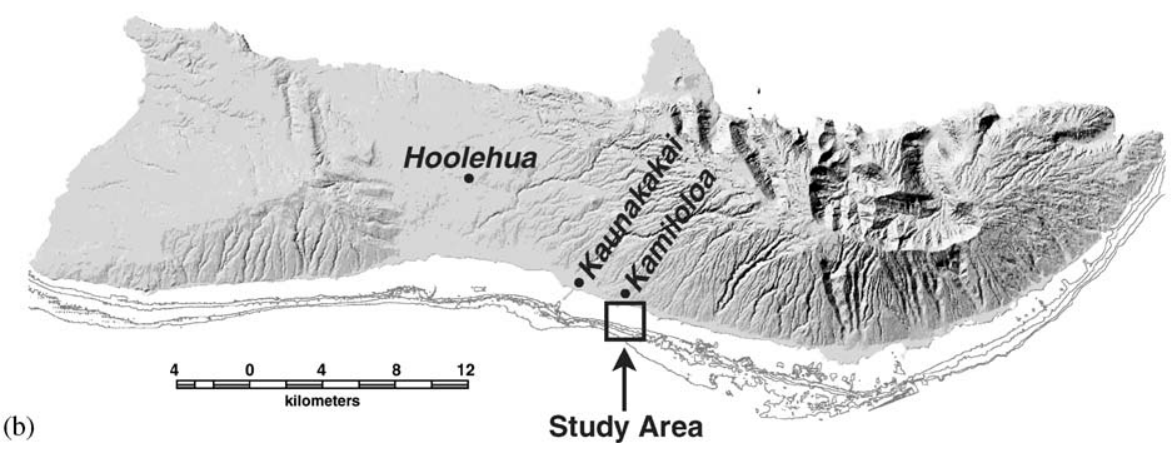

Fig. 1. Map of the study area. (a) Map of the 7 main Hawaiian Islands showing the location of Molokai and the relatively protected south shore. The isobaths are every $100 \mathrm{~m}$ from the shoreline out to $1000 \mathrm{~m}$, below which the isobaths are every $1000 \mathrm{~m}$. (b) Hillshaded digital elevation model of Molokai showing the morphology of the island and the location of areas discussed in the text. The isobaths are every $10 \mathrm{~m}$ from the shoreline out to $40 \mathrm{~m}$.

(58-65\%; Calhoun and Field, 2002) across the entire reef tract; the fine-grained component varies between terrestrial sediment derived from the erosion of the island's volcanics and calcareous marine sediment. The inner portion of the reef flat is covered by a wedge of muddy sand (90-95\% of the silt and finer grain sizes are terrigenous in origin) that pinches out roughly $200-300 \mathrm{~m}$ off- shore. Most of this fine-grained terrestrial sediment makes it way to the shoreline by overland flow or stream discharge during the infrequent but intense Kona storms (see next section for explanation). From this point out to roughly $500 \mathrm{~m}$ offshore an ancestral reefal hardground is exposed that is typically covered by algae. Ridge-andrunnel structure characterizes the reef flat from 
$500 \mathrm{~m}$ out to the reef crest roughly $1000 \mathrm{~m}$ offshore. The coral ridges are covered by low percentages of live coral and the runnel depressions are filled by calcareous sediment. The reef crest, which is the location where most deepwater waves break, is well defined along most of the reef off southern Molokai and is predominately covered by encrusting coralline algae and robust lobe and encrusting corals. Offshore of the reef crest, from depths of $3-30 \mathrm{~m}$, lies the fore reef, typically the zone of highest coral cover and generally characterized by $1-3 \mathrm{~m}$ high shorenormal spur- and-groove structures. The sediment on the fore reef is predominantly calcareous, with a very thin surface coating of terrestrial sediment often observed during scuba dives in relatively low-energy conditions.

\subsection{Oceanography and meteorology}

There have been no previous studies other than Ogston et al. (in press) describing the nature of tides or currents around the island of Molokai and thus we will limit our overview of the oceanography to the previously documented regional wave climate. The wave climate off Molokai is dominated by four end-members: the North Pacific swell, Northeast Trade wind waves, Southern Ocean swell, and Kona storm waves (Moberly and Chaimberlin, 1964). Due to the island's long axis being roughly east-west, the North Pacific swell is not a factor along the central portion of the fringing reef of the island's south shore. Northeast Trade wind waves occur throughout the year but are largest from April through November when the Trade winds are the strongest (typically $10-20 \mathrm{~m} / \mathrm{s}$; Ogston et al., in press); these waves have significant wave heights $\left(H_{s}\right) \sim 1-4 \mathrm{~m}$ but have short periods, with dominant wave periods $\left(T_{d}\right) \sim 5-8 \mathrm{~s}$. The Southern swell is generated by storms in the Southern Ocean during the Southern Hemisphere winter and while they are typically small $\left(H_{S} \sim 1-2 \mathrm{~m}\right)$, they have long periods $\left(T_{d} \sim 14-25 \mathrm{~s}\right)$. Kona storm waves from the south occur when local fronts or extratropical lows pass through the region and are neither frequent nor consistent in their occurrence.
Kona storm waves typically have $H_{s} \sim 3-5 \mathrm{~m}$ and $T_{d} \sim 8-12 \mathrm{~s}$.

Precipitation patterns on the island are primarily a function of two of the four storm patterns: the Northeast Trade winds and Kona storms. The Northeast Trade winds primarily strike the northeast side of the island, are steered around the east Molokai volcano and most often obliquely approach the reef off Kamiloloa from the southeast (Fletcher et al., 2002). Due to orographic effects associated with the high east Molokai shield volcano, most of the precipitation (200$400 \mathrm{~cm} / \mathrm{yr}$ ) falls on the northeast section of the island while most of the south-central and the entire west side of the island receive less than $60 \mathrm{~cm} / \mathrm{yr}$ on average (State of Hawaii, 2001).

\section{Field experiment and methods}

Bottom-mounted instrument packages were deployed at four locations across the fringing reef off Kamiloloa during the summer of 2001 (Fig. 2). The shallowest (REEFPROBE-1) tripod was deployed from shore using a towed pontoon boat; the three instrument packages on the fore reef in depth of 3-10 $\mathrm{m}$ were deployed by divers from the $R / V$ Alyce $C$ on August 1st. The instruments were deployed concurrently for a 3-month span between August and November. Due to a battery failure in one of the instruments, however, only 40 days of continuous data from all sensors were collected between August 5th through September 14th (JD 216-256). A summary of the sensors and sampling schemes for the instrument packages is provided in Table 1.

The shallowest station, REEFPROBE-1, was in $1.2 \mathrm{~m}$ of water on the reef flat roughly $500 \mathrm{~m}$ offshore at the transition from algal-covered pavement to ridge-and-runnel structure where live coral was first observed. The upper few centimeters of sediment at the site was a bimodal and poorly sorted, finely skewed silty sand, with a mean grain size $\left(D_{50}\right)$ of $0.32 \mathrm{~mm}$ (medium sand); less than $9 \%$ of the sample was silt and clay. Ripples were not observed during any of our observations at this site over the previous 2 years. Due to extremely high biofouling, the 

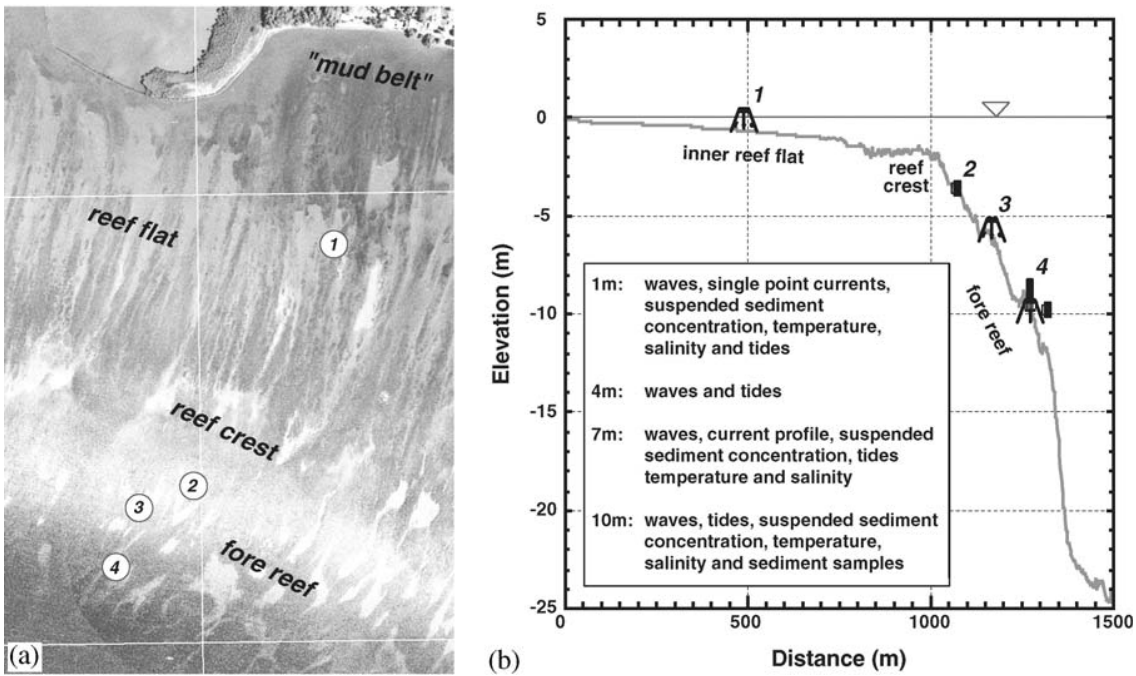

Fig. 2. Location of the instrument packages. (a) Aerial photograph of the reef off Kamiloloa showing the spatial distribution of the instruments and some of the dominant morphological regions. The shore-normal dark lineations on the reef flat are coral ridge-andrunnel structures while on the fore reef they are spur-and-groove structures. Light areas all across the reef are patches of unconsolidated calcareous sediment. (b) Cross-section of the reef from $2 \mathrm{~m}$ resolution SHOALS lidar data showing the relative position of the instrument packages on the reef and the parameters they are measuring (see inset). The vertical exaggeration is $50: 1$.

transmissometer data were unusable and are not presented here; the optical backscatter sensor (OBS) was not afftected by the bioufouling due to anti-biofouling material applied to the lens before calibration.

The shallowest fore-reef station along the $4 \mathrm{~m}$ isobath was occupied solely by a bottom-mounted wave gauge that was located in a sand-filled coral groove roughly $10 \mathrm{~m}$ wide (alongshore) and $20 \mathrm{~m}$ long (cross-shore). The groove was depressed roughly $0.3 \mathrm{~m}$ below the surrounding coral spurs which had little $(<5 \%)$ live coral cover. The upper few centimeter of sediment at the wave gauge were well sorted, coarsely skewed clean carbonate sand, with a mean grain size $\left(D_{50}\right)$ of $0.22 \mathrm{~mm}$ (fine sand); almost $1 \%$ of the sample was gravel and less than $2 \%$ of the sample was silt and clay. Wave orbital ripples, with heights $\left(h_{r}\right)$ on the order of $5 \mathrm{~cm}$ and wavelengths $\left(\lambda_{r}\right)$ of roughly $30 \mathrm{~cm}$, were observed at this site during the wave gauge's deployment and recovery.

The next deepest station on the fore reef along the $7 \mathrm{~m}$ isobath was occupied by a second benthic boundary layer tripod (REEFPROBE-2), which was equipped with a suite of instruments similar to REEFPROBE-1. Unlike the shallower REEFPROBE-1, however, REEFPROBE-2 was equipped with an upward-looking acoustic doppler current profiler (ADCP), it lacked a transmissometer, and had a downward-looking acoustic doppler velocimeter (ADV) instead of the bi-directional electromagnetic current meter deployed on the shallower tripod. By mounting the ADV in a downwardlooking orientation, it was possible to collect data on the range of the sensor to the bed, making it feasible to look at accretion or erosion of the bed. Like the wave gauge in $4 \mathrm{~m}$ of water, REEFPROBE-2 was also situated in a sand-filled groove between two coral spurs. The dimensions of this groove were similar, roughly $15 \mathrm{~m}$ in width (alongshore) and $35 \mathrm{~m}$ long (cross-shore). The tripod was located approximately halfway across the sediment-filled groove and thus about $8 \mathrm{~m}$ alongshore from each spur. The coral spurs to either side of the REEFPROBE-2 tripod were less than $0.8 \mathrm{~m}$ high and thus did not likely cause topographic steering except very close to the bed. The bed material at the REEFPROBE-2 site was 
Table 1

Instrumentation and sampling schemes during the experiment

\begin{tabular}{|c|c|c|c|c|c|}
\hline Depth $(\mathrm{m})$ & Instruments & $\begin{array}{l}\text { Elevation } \\
(\mathrm{m})\end{array}$ & $\begin{array}{l}\text { Sampling } \\
\text { rate (s) }\end{array}$ & $\begin{array}{l}\text { Burst length } \\
\text { (s) }\end{array}$ & $\begin{array}{l}\text { Burst } \\
\text { interval (s) }\end{array}$ \\
\hline \multirow[t]{5}{*}{1} & Electromagnetic bi-directional current meter & 0.2 & 0.5 & 512 & 3600 \\
\hline & Pressure sensor & 0.3 & 0.5 & 512 & 3600 \\
\hline & Optical backscatter sensor & 0.2 & 0.5 & 512 & 3600 \\
\hline & Transmissometer $^{\mathrm{a}}$ & 0.2 & 0.5 & 512 & 3600 \\
\hline & Conductivity and temperature sensor & 0.5 & - & - & 120 \\
\hline 4 & Wave gauge & 0.5 & 0.5 & 512 & 3600 \\
\hline \multirow[t]{7}{*}{7} & $5 \mathrm{MHz}$ Acoustic doppler velocimeter & 0.2 & 0.5 & 512 & 3600 \\
\hline & Pressure sensor & 0.2 & 0.5 & 512 & 3600 \\
\hline & Optical backscatter sensor ${ }^{\mathrm{b}}$ & 0.2 & 0.5 & 512 & 3600 \\
\hline & Optical backscatter sensor ${ }^{\mathrm{b}}$ & 0.4 & 0.5 & 512 & 3600 \\
\hline & Temperature sensor & 1.0 & 1.0 & 120 & 900 \\
\hline & $1500 \mathrm{KHz}$ acoustic doppler current & $2.0-7.0$ & & & \\
\hline & Profiler & every 0.5 & 1.0 & 120 & 900 \\
\hline \multirow[t]{4}{*}{10} & Wave gauge & 0.5 & 0.5 & 512 & 3600 \\
\hline & Optical backscatter sensor ${ }^{\mathrm{a}}$ & 1.0 & - & - & 240 \\
\hline & Conductivity and temperature sensor & 0.5 & - & - & 120 \\
\hline & Rotary sediment trap & 1.3 & - & $\begin{array}{l}414720 \\
\text { (4.8 days) }\end{array}$ & - \\
\hline
\end{tabular}

${ }^{\mathrm{a}}$ Failed due to severe biofouling.

${ }^{\mathrm{b}}$ Failed due to electrical interference.

very well sorted, coarsely skewed clean carbonate sand, with a mean grain size $D_{50}$ of $0.22 \mathrm{~mm}$ (fine sand); less than $3 \%$ of the sample was silt and clay. Wave orbital ripples, with $h_{r} \sim 2 \mathrm{~cm}$ and $\lambda_{r} \sim 20 \mathrm{~cm}$ were observed during the tripod's deployment and recovery. Due to severe biofouling and electronic interference between the two OBSs, their data was unreliable and thus will also not be presented here.

A third instrumented tripod was placed in $10 \mathrm{~m}$ of water on the fore reef. This held a time-series sediment trap that contained 21 sediment collection bottles, each of which rotated under the trap for approximately 4.8 days. The trap collection cylinder was $0.75 \mathrm{~m}$ high by $0.20 \mathrm{~m}$ wide and tapered into a funnel $0.15 \mathrm{~m}$ high. Located at the top of the cylinder was a $0.10 \mathrm{~m}$ deep hexagonal baffle with approximately $0.01 \mathrm{~m}$ openings. The baffle prevented large organisms from living in the trap and reduced, but did not eliminate, water circulation inside the trap induced by tidal currents and oscillatory currents caused by surface waves. The trap opening was $1.3 \mathrm{~m}$ above bottom. The sediment trap was used in this study to obtain a relative measure of resuspension intensity over time and to collect some of the resuspended material for physical and chemical characterization. One needs to keep in mind that because of the high-energy of this environment, the trap did not measure net vertical flux to the coral reef surface. This is because material falling into the trap has a much lower potential for resuspension than the same material that settles on the adjacent reef surface. In addition, the trap was likely to preferentially collect coarser particle sizes because of their higher settling velocity than finer particles. Particles with a slow settling velocity relative to the circulation and exchange of water contained in the trap can be underrepresented in the sample collected.

A self-contained wave gauge, similar to the one deployed along the $4 \mathrm{~m}$ isobath, was also mounted on the rotary sediment trap tripod. The bed at this location was an intermittent to thin $(0.0-0.2 \mathrm{~m})$, patchy layer of coarse-grained sand overlying a 
coral pavement covered by numerous $5-15 \mathrm{~cm}$ high coralline algae plants of the Halimeda genus. The sediment had a $D_{50}$ of $0.13 \mathrm{~mm}$ (fine to very fine sand); the mode, representing $75 \%$ of the surficial bed size-distribution, was between 0.10 and $0.25 \mathrm{~mm}$.

The bulk grain sizes of bed samples were analyzed using both Beckman Coulter Counter (silt and clay) and 2-m settling tubes (sand), and within each grain size fraction the percent carbonate was determined with a UIC Coulometer. The carbonate and terrigenous percentages for the sand, silt and clay size fractions were determined using the methodology developed by Barber (2002). Optical sensors were calibrated with seabed sediment obtained from the instrument sites as well as with water column samples obtained throughout the deployment period following the methods outlined by Ogston et al. (in press).

Surface wind data were collected hourly at the Molokai airport in Hoolehua roughly $12 \mathrm{~km}$ to the northwest of the study site. Because the airport is located in the saddle between the two shield volcanoes, strong topographic steering occurs and thus the data were only used qualitatively (i.e. strong winds from the northwest or weak winds from the south).

The wave spectrum was evaluated using an ensemble and band-averaging power autospectrum. This routine applied a $256 \mathrm{~s}$ Hanning window with $50 \%$ overlap and a linear de-trend to replace the truncated degrees of freedom and hence increase the reliability of the results. The dominant wave period $\left(T_{d}\right)$ was determined after spectrally correcting the spectrum for pressure attenuation with depth using linear wave theory and a high frequency cut-off of $0.33 \mathrm{~Hz}$. The significant wave height $\left(H_{s}\right)$ was calculated spectrally using the Birkemeier et al. (1989) method and a bandwidth of 0.33 to $0.04 \mathrm{~Hz}(3-25 \mathrm{~s})$.

Simple band-pass filtering was performed to evaluate the relative contributions of different components to the near-bed currents. The semidiurnal and diurnal tidal components were assumed to be equivalent to the time-series output from the harmonic analysis band-pass filtered at 10-16 and 20-28 h, respectively, following Wright et al. (1999). Supratidal currents were 3-10 h band- pass filtered, while the subtidal currents were $36 \mathrm{~h}$ low-pass filtered (Wright et al., 1999).

Due to biofouling and electronic interference between the OBSs, only qualitative estimates of the amount of suspended matter over the fore reef were available through the use of the acoustic backscatter $(B k)$ in $\mathrm{dB}$ recorded by the ADV and ADCP. This method has been used successfully for both qualitative and quantitative measurements of suspended sediment concentrations $(C)$ in numerous studies (e.g. Thorne et al., 1991; Osborne et al., 1994; Reichel and Nachtnebel, 1994; Holdaway et al., 1999); a comprehensive review of the theory and application is presented by Thorne and Hanes (2002). The raw $B k$ were corrected for signal strength decay with distance from the transducers due to spreading and absorption using the method outlined by Sontek (1997). Due to the lack of colocated measurements of $C$, it was impossible to translate the corrected $B k$ to units of concentration and thus only the corrected $\mathrm{dB}$ values are presented as a proxy for suspended sediment concentrations $(C)$.

\section{Results}

\subsection{Physical forcing}

Persistent Trade winds and Trade-wind waves (Fig. 3) characterized the period of deployment. Notable exceptions to this were a wind event out of the south and concurrent decrease in wave height of roughly a meter between August 24th and 28th (JD 236-240) and another decrease of the same magnitude in the wave field between September 2nd and 9th (JD 245-252). Both of these periods coincided with decreases in barometric pressure and likely coincided with the passage of fronts or tropical depressions near the Hawaiian Island chain. Although long-term trends are visible in both the wind and barometric pressure time series, these records are dominated by the daily cycle of island heating due to insolation, which causes air over the islands to rise, decreasing barometric pressure and increasing local Trade wind velocities (Fletcher et al., 2002). 


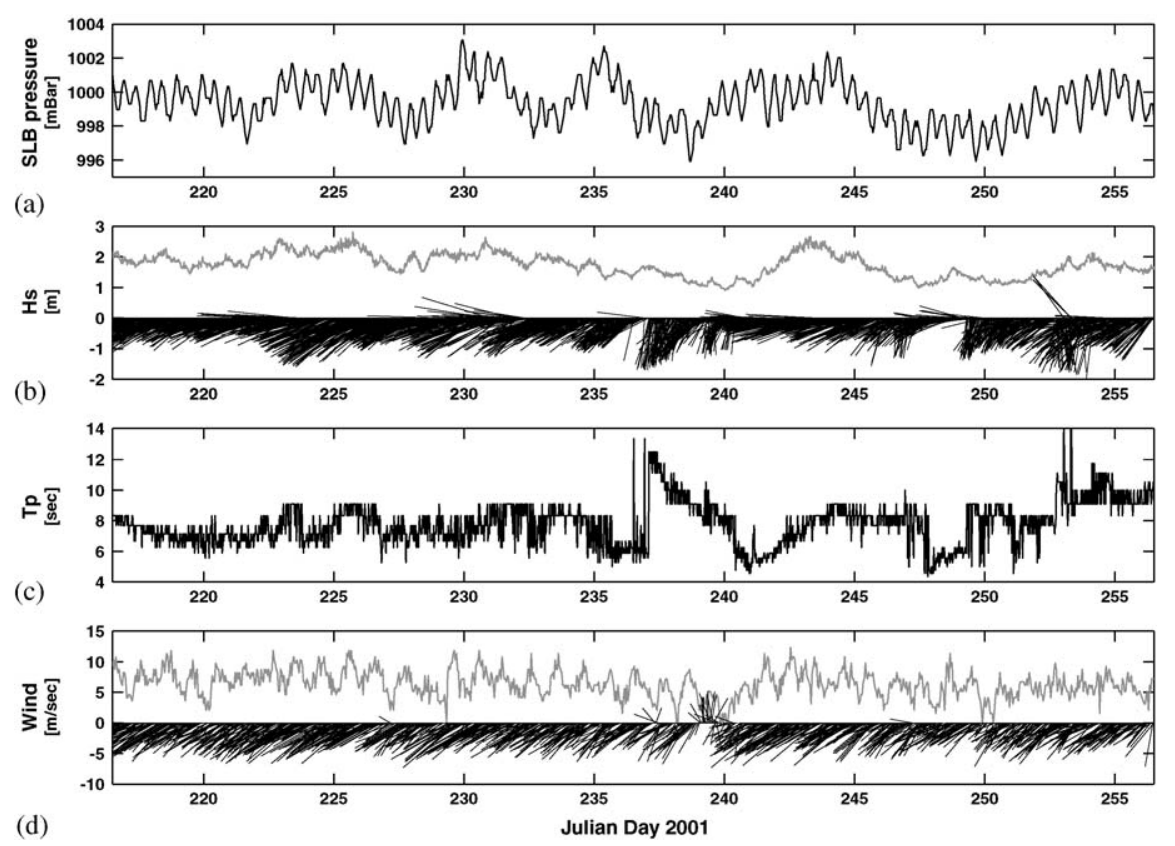

Fig. 3. Meteorologic and oceanographic forcing during the field experiment. (a) Barometric pressure from the Hoolehua Airport, Molokai. (b) Wave data from the Mokapu Waverider buoy in $100 \mathrm{~m}$ of water off northeast Oahu, roughly $75 \mathrm{~km}$ from the field site. Wave height is shown in gray; wave magnitude and direction are shown in black. (c) Wave period from the Mokapu buoy. (d) Wind speed is shown in gray; wind magnitude and direction are shown in black; from the Hoolehua Airport, Molokai. Although long-term trends are visible in all of the records, the high-frequency fluctuations are dominated by daily insolation and Trade wind cycles.

\subsection{Tide and wave measurements}

The deployment encompassed almost three complete spring-neap tidal cycles, with the tides off southern Molokai being of the mixed semidiurnal type (Fig. 4). The mean tidal range was roughly $0.6 \mathrm{~m}$, with a maximum spring range of more than $0.9 \mathrm{~m}$ and a minimum neap range just under $0.4 \mathrm{~m}$. There was significant variation in both tidal range and relative height between the tides observed over the fore reef and those measured on the shallow reef flat. Two co-located pressure sensors at the $7 \mathrm{~m}$ REEFPROBE-2 site varied by less than $0.05 \mathrm{~m}$ and had an $R^{2}=0.99$; the resolution of the pressure sensors was less than $0.01 \mathrm{~m}$. Since the pressure sensors on the different instrument packages were not surveyed-in to a set datum, the following discussions of sea level differences are all relative and not absolute. The difference between the tidal elevations measured at the $7 \mathrm{~m}$ REEFPROBE-2 site on the fore reef and at the REEFPROBE-1 package on the reef flat, however, were often more than $0.20 \mathrm{~m}$; the correlation between these two mean water depth time series was lower, with an $R^{2}=0.82$. The maximum cross-correlation between the two was $\sim 0.92$ and occurred at $+1 \mathrm{~h}$ lag, indicating that on average the reef flat tidal elevation peaked $1 \mathrm{~h}$ after the tide on the fore reef.

The discrepancies noted in the timing and relative heights in water depth concurrently observed over the reef flat and fore reef often caused a significant slope in sea surface across the reef. The difference in water depth between the reef flat and fore reef was greater during the low tides, with $92 \%$ of the low tides displaying differences in tidal elevation across the reef. In terms of these differences in sea surface elevation across the reef relative to phases of the tidal cycle, the most consistent variations were observed during the transition from spring to neap conditions and during the peak neap tides. During neap 


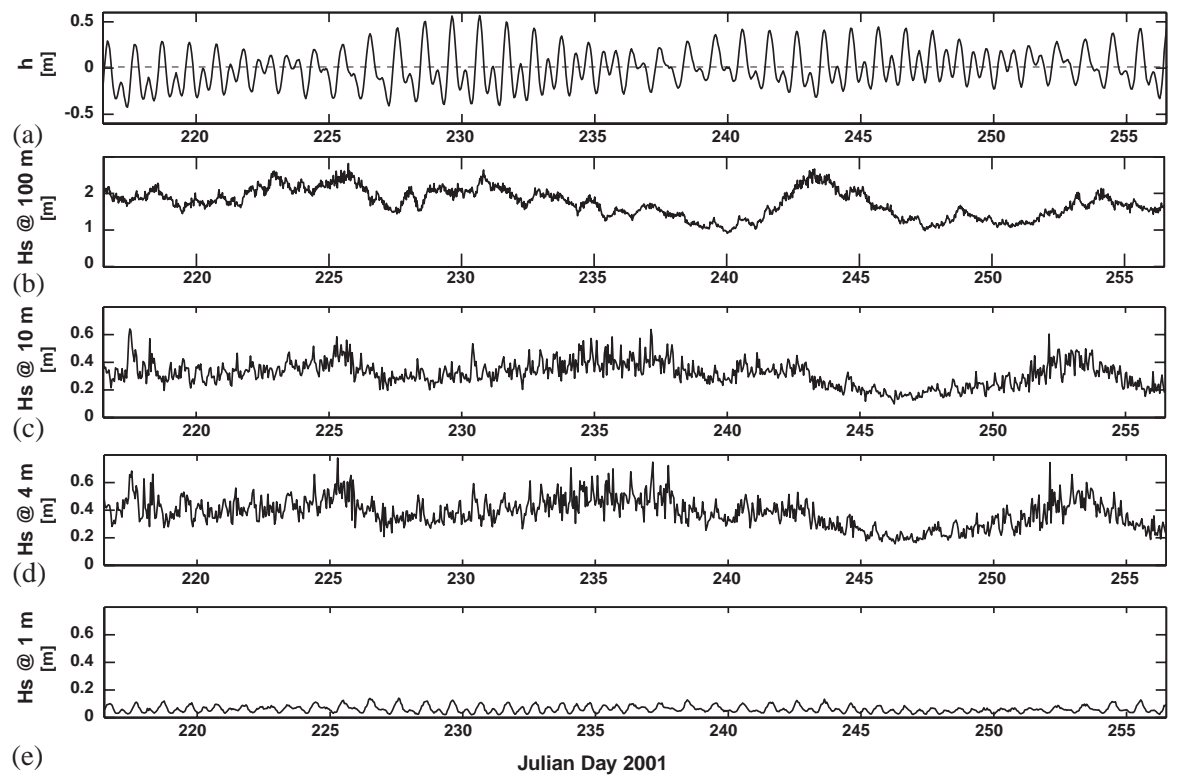

Fig. 4. Water depth and wave height during the experiment. (a) Tidal height at the $10 \mathrm{~m}$ instrument station. (b) Wave data from the Mokapu Waverider buoy in $100 \mathrm{~m}$ of water off northeast Oahu, roughly $75 \mathrm{~km}$ from the field site. (c) Wave height at the $10 \mathrm{~m}$ instrument station on the fore reef. (d) Wave height at the $4 \mathrm{~m}$ instrument station on the fore reef. (e) Wave height at the REEFPROBE-1 on the reef flat. Note the much smaller wave heights on south Molokai's fore reef relative to the deep-water wave heights measured at the Mokapu buoy. This is due to the sheltering of the reef from the dominant northerly North Pacific swell and northwesterly Trade wind waves by the island of Molokai. The large decrease between the fore reef and the reef flat is due to wave breaking at the reef crest and the extreme shallowness of the reef flat.

tides, the lower high tides were typically more than $0.10 \mathrm{~m}$ higher on the reef flat than on the fore reef, while the higher lows tended to be $0.05-0.10 \mathrm{~m}$ higher on the reef flat. During the spring to neap transitional periods, the higher highs were often more than $0.10 \mathrm{~m}$ higher on the reef flat than the fore reef, while the lower lows on the reef flat were typically between 0.05 and $0.10 \mathrm{~m}$ higher than those tidal heights measured on the fore reef. These observations suggest that resistance of tidal flow at the reef crest delays the tidal phase and forces the sloping sea surface between the fore reef and reef flat.

The south shore of Molokai is significantly sheltered to open ocean swell. While the Mokapu Waverider buoy (Fig. 4b) recorded a mean $H_{s} \pm 2 \sigma=1.74 \pm 0.76 \mathrm{~m}$ throughout the study period, the deepest wave gauge at $10 \mathrm{~m}$ in the study area (Fig. 4c) measured a mean $H_{s} \pm 2 \sigma$ $=0.32 \pm 0.18 \mathrm{~m}$. Waves were typically more than $18 \%$ higher (mean $H_{s} \pm 2 \sigma=0.38 \pm 0.21 \mathrm{~m}$ ) at the
$4 \mathrm{~m}$ wave gauge (Fig. 4d) than at the $10 \mathrm{~m}$ wave gauge, showing the substantial shoaling effects and/or refraction over less than $250 \mathrm{~m}$ horizontally and $6 \mathrm{~m}$ vertically on the hydraulically rough fore reef.

Field observations and data made it clear that the waves measured on the fore reef underwent breaking at the reef crest between the $4 \mathrm{~m}$ depth (Fig. 4d) and $1 \mathrm{~m}$ depth (Fig. 4e) instrument stations. The breaking caused not only a decrease in mean $H_{s}$ of $78 \%$, but also change in frequency structure such that the mean $T_{d}$ typically decreased by $79 \%$, resulting in a reduction in mean wave power of $97 \%$ as the waves break and propagate across the reef crest. The mean wave transmission coefficient $\left(K_{t}\right.$, Nelson and Lesleighter, 1985) between the fore reef at $4 \mathrm{~m}$ depth and the $1 \mathrm{~m}$-deep reef flat was 0.22 , with a range of 0.09-0.67. A strong coupling between the wave heights and water depth on the reef flat existed and suggests that the water depth on the reef flat limits 
wave height. The dependence on $H_{s}$ on water depth $(h)$ on the reef flat is illustrated by the mean $H_{s}$ being $\sim 3.8$ times higher on the reef flat during high tidal stages than at low tide $(0.19 \pm 0.06 \mathrm{~m}$ versus $0.05 \pm 0.03 \mathrm{~m}$, respectively). The very low mean $T_{d}(1.3 \pm 0.4 \mathrm{~s})$ on the reef flat and its very high positive correlation with $h\left(R^{2}=0.99\right)$ reflect the local origin of these Trade wind waves on the fetch-limited reef flat and their strong dependency on $h$. On the other hand, the much longer mean $T_{d}$ $(6.1 \pm 3.7 \mathrm{~s})$ measured on the fore reef are indicative of long-period South swell or local Trade wind waves out in the channels between the islands of Molokai, Maui and Lanai.

\subsection{Currents, physical properties and sediment suspension on the reef flat}

Net near-bed flow at $0.2 \mathrm{~m}$ above the bed (mab) on the reef flat over the deployment was downwind to the west and slightly offshore (Fig. 5). The principal axis of the currents is obliquely along- shore, with the flow moving slightly onshore and upwind to the east during the rising tide and offshore and downwind to the west during the falling tide. The cross-shore currents $\left(X_{S}\right)$ are typically $30 \%$ or so the magnitude of the alongshore currents $\left(A_{s}\right)$ and are apparently linked to $h$ on the reef flat, similar to the observations at Tague Reef in the US Virgin Islands by LugoFernandez et al. (1998). The 10-26h band-pass filtered onshore currents $\left(X_{S}\right)$ display an inverse correlation $\left(R^{2}=0.324\right)$ with $h$ that was significant above the $0.1 \%$ level. The mean current speeds with 95\% confidence intervals and maximum speeds contributed by each component during the deployment are summarized in Table 2. The diurnal (10-14h band-pass filtered) tidal and subtidal ( $36 \mathrm{~h}$ low-pass filtered) currents were generally twice as strong as the supratidal $(5 \mathrm{~h}$ high-pass filtered) components. Incident-frequency wave orbital motions (3-30 s band-pass filtered) dominated the near-bed flow with speeds more than three times the supratidal current speeds and
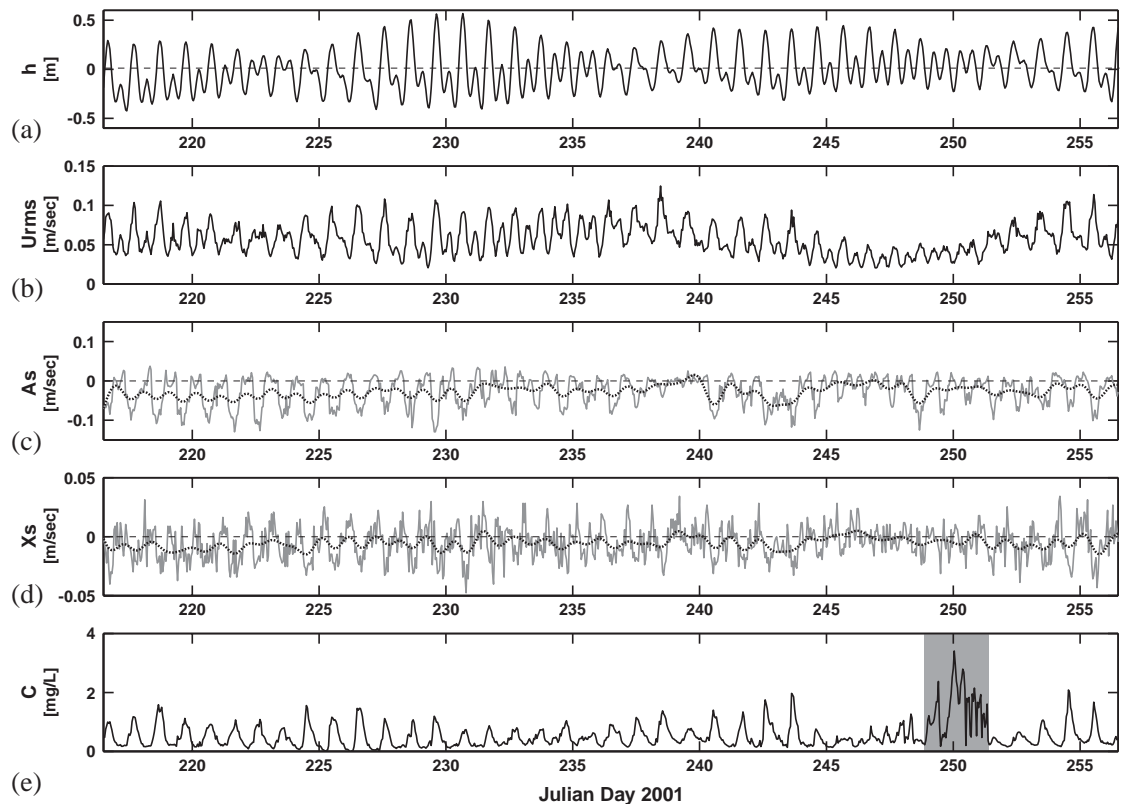

Fig. 5. Data from the REEFPROBE-1 tripod on the reef flat. (a) Tidal height. (b) Root-mean-squared orbital wave velocity. (c) Alongshore current velocity, with positive values to the east. (d) Cross-shore current velocity, with positive values onshore. (e) Suspended sediment concentration. Solid lines are hourly data; dotted lines are 36-h low-pass filtered data. The gray box in the suspended sediment concentration time series denotes a period when algae was wrapped around the OBS sensor, resulting in false readings. Note the strong dependence of waves, currents, and sediment suspension on water depth over the shallow reef flat. 
Table 2

Magnitudes of flow components measure on the reef flat and fore reef

\begin{tabular}{|c|c|c|c|c|}
\hline Location & Height above bed (m) & Components & Mean $\pm 2 \sigma(\mathrm{cm} / \mathrm{s})$ & Maximum $(\mathrm{cm} / \mathrm{s})$ \\
\hline \multirow[t]{5}{*}{ Reef flat } & \multirow[t]{5}{*}{0.2} & Wave orbital motions & $5.3 \pm 3.7$ & 12.7 \\
\hline & & Supratidal currents & $1.1 \pm 1.4$ & 5.9 \\
\hline & & Semi-diurnal tidal currents & $1.3 \pm 1.5$ & 4.1 \\
\hline & & Diurnal tidal currents & $2.2 \pm 2.8$ & 5.8 \\
\hline & & Subtidal currents & $2.5 \pm 2.6$ & 6.5 \\
\hline \multirow[t]{13}{*}{ Fore reef } & \multirow[t]{5}{*}{0.2} & Wave orbital motions & $4.1 \pm 4.9$ & 14.8 \\
\hline & & Supratidal currents & $1.2 \pm 1.5$ & 6.6 \\
\hline & & Semi-diurnal tidal currents & $2.4 \pm 3.4$ & 7.3 \\
\hline & & Diurnal tidal currents & $2.1 \pm 2.8$ & 6.3 \\
\hline & & Subtidal currents & $1.7 \pm 2.2$ & 5.6 \\
\hline & \multirow[t]{4}{*}{2.0} & Supratidal currents & $2.4 \pm 2.8$ & 9.1 \\
\hline & & Semi-diurnal tidal currents & $4.7 \pm 6.7$ & 14.9 \\
\hline & & Diurnal tidal currents & $4.4 \pm 6.2$ & 13.1 \\
\hline & & Subtidal currents & $3.1 \pm 4.5$ & 14.0 \\
\hline & \multirow[t]{4}{*}{6.0} & Supratidal currents & $3.8 \pm 5.1$ & 18.6 \\
\hline & & Semi-diurnal tidal currents & $5.6 \pm 6.9$ & 16.4 \\
\hline & & Diurnal tidal currents & $5.9 \pm 7.9$ & 18.8 \\
\hline & & Subtidal currents & $6.5 \pm 7.1$ & 25.0 \\
\hline
\end{tabular}

$50 \%$ higher than the subtidal current speeds. The root-mean-squared (RMS) wave orbital velocity time series appears to be primarily a function of water depth over the reef flat, which is strongly modulated at lower frequencies by variations in the deep-water wave field. Daily water temperature and salinity fluctuations on the reef flat were on the order of $2^{\circ} \mathrm{C}$ and $1.0 \mathrm{psu}$, respectively, and attained maximum daily fluctuations of more than $4{ }^{\circ} \mathrm{C}$ and $2 \mathrm{psu}$, respectively. Water flowing onto the reef flat from the channel during the rising tide was typically cooler and higher in salinity than the water observed moving offshore during the falling tide.

The prominent feature on the $C$ time series is the peak between August 6th-8th (JD 249-251); this anomalous peak appears independent of $H_{s}, A_{s}$ and $X_{S}$ both fore reef and reef flat. This feature is believed to be the artifact of biofouling, similar to the observations by Ogston et al. (in press). The remaining high-quality time series of suspended sediment concentration $(C)$ had a mean $\pm 2 \sigma$ of $0.55 \pm 0.89 \mathrm{mg} / 1$ and was strongly modulated by the tides. Hourly burst mean concentrations often exceeded $5 \mathrm{mg} / \mathrm{l}$ and instantaneous concentrations were observed to exceed $40 \mathrm{mg} / 1$. A positive correlation between 10-26h band-pass filtered $h$ and $C$ was observed and had an $R^{2}=0.328$, which was significant above the $0.1 \%$ level. Consistent with previous analyses (Ogston et al., in press), the highest $C$ were observed when high tides occurred during the afternoon when the Trade winds blew the strongest. The $10-26 \mathrm{~h}$ band-pass filtered $C$ also demonstrated an inverse correlation $\left(R^{2}=\right.$ $0.36)$ with $X_{s}$, which was also significant above the $0.1 \%$ level. The correlations between $C, h$ and $X_{s}$ demonstrate that higher $C$ typically occurred at and following high tides when larger depth-limited waves were able to propagate across the reef flat and the maximum current speeds were generated as the tide falls, apparently transporting sediment offshore.

\subsection{Currents, physical properties and sediment suspension on the fore reef}

Flows and sediment suspension on the fore reef in $7 \mathrm{~m}$ depth will be broken down into two categories based on the elevation of the sensors 
recording the data: near-bed ( $0.2 \mathrm{mab})$ and mid-toupper water column (2.0-6.0 mab).

\subsubsection{Near-bed observations on the fore reef}

Mean and net near-bed currents were primarily downcoast to the west and slightly offshore (Fig. 6); mean $A_{s}$ were twice as strong as mean $X_{S}(0.04 \pm 0.05 \mathrm{~m} / \mathrm{s}$ versus $0.02 \pm 0.03 \mathrm{~m} / \mathrm{s})$. As shown in Table 2, the wave-orbital motions were twice as strong as any of the supratidal, tidal or subtidal currents. The mean speeds at this depth on the fore reef were roughly the same as those measured at the same height above the bed on the reef flat, which has a much smaller total water depth, with $h \sim 7 \mathrm{~m}$ on the fore reef versus $\sim 1 \mathrm{~m}$ on the reef flat. A difference between the near-bed flow on the fore reef and the reef flat was that the semi-diurnal tidal currents on the fore reef were almost twice those observed on the reef flat while the low-frequency subtidal currents were only twothirds those measured on the reef flat. The principal axis of these near-bed flows on the fore reef were more shore-parallel than those observed along the reef flat, which had a greater cross-shore component. Near the bed, $A_{s}$ often decreased and offshore flow $\left(-X_{S}\right)$ increased when $H_{s}$ were largest (JD 217-225, 235-238 and 252-253).

The acoustic backscatter, $B k$, observed near the bed on the fore reef is highly coherent with the unfiltered $H_{s}$ time series $\left(R^{2}=0.78\right)$ and loosely correlated with $h$; the correlation between $B k$ and $H_{s}$ is significant above the $0.1 \%$ level. This very high correlation suggests that wave-induced shear stresses are the dominant mechanism controlling increased near-bed $B k$ on the fore reef. The $36 \mathrm{~h}$ low-pass filtered $X_{S}$ is also well correlated with $B k$, although inversely, demonstrating a increase in $B k$ relative to offshore flow $\left(-X_{s}\right)$; this correlation, too, is significant above the $0.1 \%$ level $\left(R^{2}=0.36\right)$.

The time series of change in bed elevation relative to the initial observation $\left(z-z_{\text {initial }}=\right.$ $\left.\Delta_{b e d}\right)$ showed that the $\Delta_{b e d}$ varied more than $0.08 \mathrm{~m}$ over the course of the deployment. Periods of highest variability in $\Delta_{b e d}$ tend to correspond not only to higher than normal $B k$ but also $H_{s}$; conversely, the low-energy period between August 2nd-7th (JD 245-250) coincided with very low $\Delta_{b e d}$ variability and lower than average $B k$. These
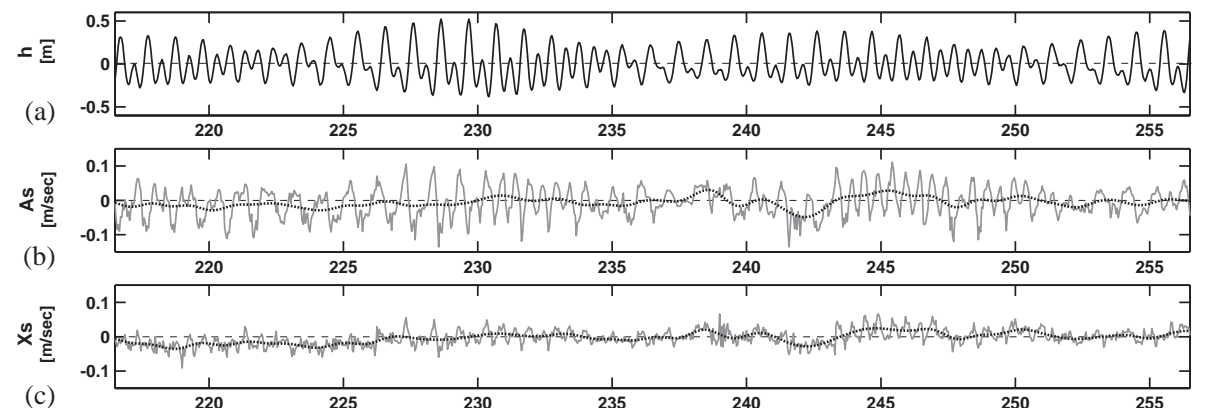

(c)

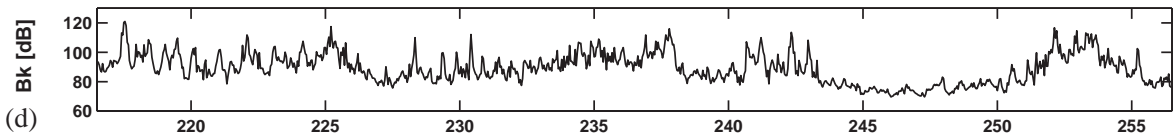

(d)

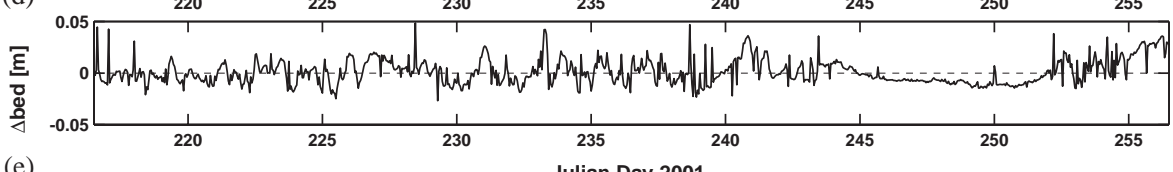

(e)

Julian Day 2001

Fig. 6. Data from the ADV and pressure sensor on the REEFPROBE-2 tripod on the fore reef. (a) Tidal height. (b) Alongshore current velocity, with positive values to the east. (c) Cross-shore current velocity, with positive values onshore. (d) Acoustic backscatter. (e) Change in bed elevation relative to the first observation, with positive values denoting accretion and negative values erosion. Solid lines are hourly data; dotted lines are 36-h low-pass filtered data. Although both components of flow display significant influence by the tides, acoustic backscatter and changes in bed elevation appear to be closely linked to the incident wave field (see Fig. 4). 
fluctuations suggest that the bed was active during these periods with larger waves and ripples were likely migrating under the sensor. During the periods of higher than normal wave energy, the mean $\Delta_{b e d}$ variability is on the order of 0.02 $0.03 \mathrm{~m}$. These values correspond well with the observations of a rippled bed both at the start and end of the deployment. The low shear stresses calculated during period from August 2nd-7th (JD 245-250; data not shown) were below the threshold necessary to suspend the bed sediment suggest that the bed was not mobile and thus unable to generate or propagate ripples during this time, resulting in $\Delta_{\text {bed }} \sim 0$.

\subsubsection{Mid-to-upper water column observations on the fore reef}

Similar to the near bed $(0.20 \mathrm{mab})$ measurements, the net flow above the bed $(2.0$ mab to
$6.0 \mathrm{mab}$ ) was also downcoast to the west and slightly offshore, with mean $A_{s}$ typically $60 \%$ greater than mean $X_{s}$ (Fig. 7). All components of the currents in the water column were often two to three times as large as those measured near the bed (Table 2). The currents in the mid to upper water column exhibit very strong, tidally modulated flow during low wave energy conditions (e.g. JD 227230 and $245-250$, Fig. 7c). These currents became less coherent with the tides during higher wave energy conditions (e.g. JD 232-237 and 250-255); specifically, the semi-diurnal tidal fluctuations virtually disappeared. This suggests that higherfrequency tidal flow over the fore reef was overprinted by net wave- and wind-driven flow. Except for near the surface at $z=6.0 \mathrm{~m}$ where the subtidal currents were higher likely due to wind-driven surface flow, the contributions by tidal and supratidal currents was similar to that observed

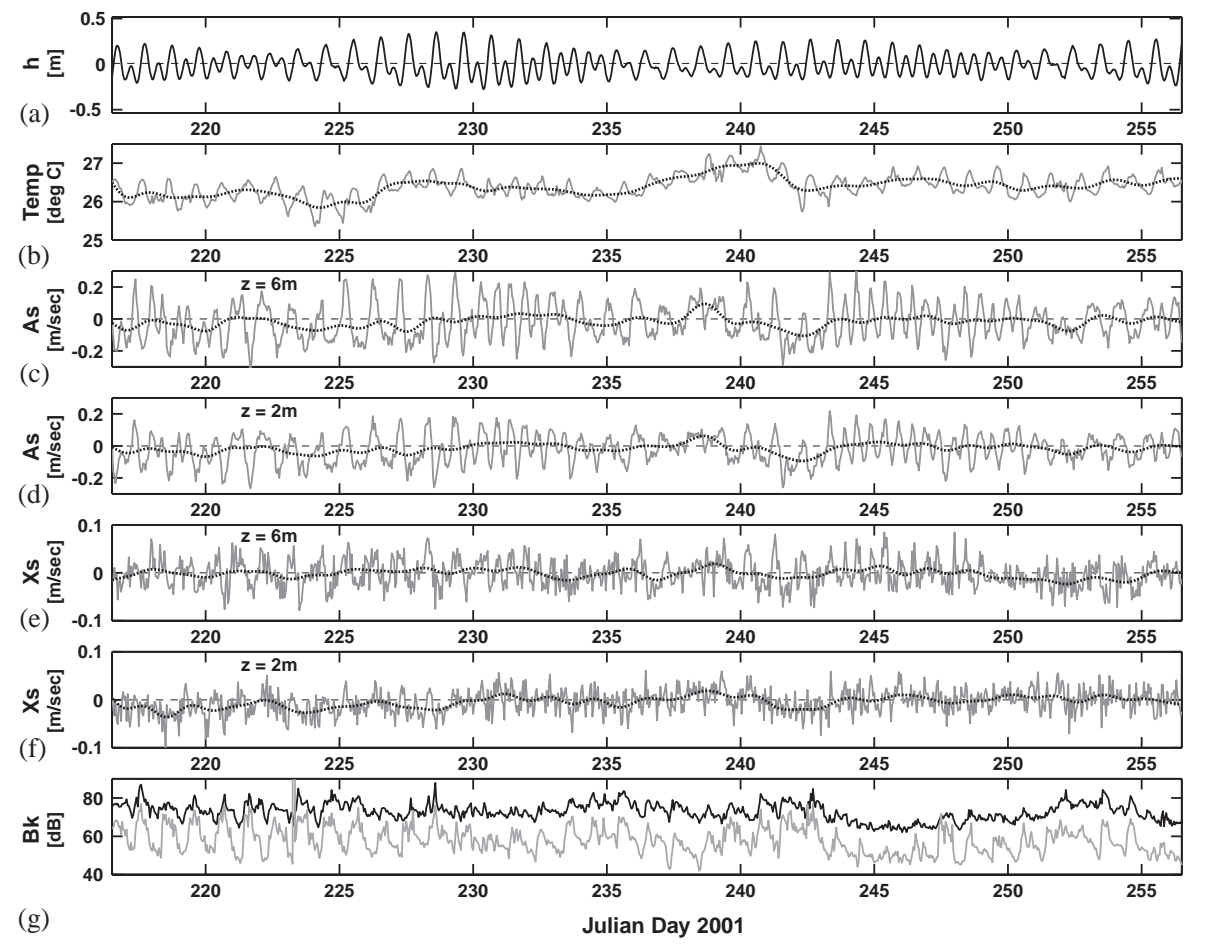

Fig. 7. Data from the ADCP on the REEFPROBE-2 tripod on the fore reef. (a) Tidal height. (b) Temperature. (c) Alongshore current velocity at $z=6.0 \mathrm{~m}$, with positive values to the east. (d) Alongshore current velocity at $z=2.0 \mathrm{~m}$. (e) Cross-shore current velocity at $z=6.0 \mathrm{~m}$, with positive values onshore. (f) Cross-shore current velocity at $z=2.0 \mathrm{~m}$. (g) Acoustic backscatter at $z=6.0 \mathrm{~m}$ (gray) and at $z=2.0 \mathrm{~m}$ (black). Solid lines are hourly data; dotted lines are 36-hour low-pass filtered data. All of the parameters are strongly modulated by tidal motions but the lower-frequency motions appear to be a function of the incident wave field (see Fig. 4). 
near the bed, with the semi-diurnal and diurnal components dominating the flow. Overall, the near surface $(6.0 \mathrm{mab})$ currents were roughly $20 \%$ greater than those at $2.0 \mathrm{mab}$. Between $2.0 \mathrm{mab}$ and $0.2 \mathrm{mab}$, current speeds decreased with the typical logarithmic velocity profile. Mean current velocities in the upper portion of the water column are on the order of wave orbital motions observed only $0.20 \mathrm{~m}$ above the bed. These high surface and low near-bed current speeds suggest that there was substantial mean shear within the water column that would help maintain particulate matter suspended in the water column. Mean shear calculated over the deployment was $0.03 \pm 0.031$ / $\mathrm{s}$ and $0.10 \pm 0.041 / \mathrm{s}$ at $2.0 \mathrm{mab}$ and $6.0 \mathrm{mab}$, respectively.

Temperature variability was much lower at $0.2 \mathrm{mab}$ on the fore reef $\left(\sigma=0.29^{\circ} \mathrm{C}\right)$ than at a similar elevation above the bed on the reef flat $\left(\sigma=1.28^{\circ} \mathrm{C}\right)$. This lower temperature variability is likely due to lower impact of solar heating because of the greater water depth on the fore reef relative to the shallow reef flat. The low-frequency modulation in temperature appears to be inversely related to wind speed $\left(R^{2}=0.39\right.$; significant above the $0.1 \%$ level) and might have been due to either or both increased surface heating when wind speeds decrease or the upwelling of deep cooler water when wind speeds are high. The higherfrequency temperature fluctuations are primarily tidal in origin and may be related to cross-shore flow, with temperature being inversely correlated with $X_{s}\left(R^{2}=0.28\right.$; significant above the $0.1 \%$ level).

In general, the $B k$ in the lower portion of the water column at 2.0 mab was higher than that observed near the surface at $6.0 \mathrm{mab}$. The near surface $B k$, however, displays much greater variability than the $B k$ lower in the water column at $2.0 \mathrm{mab}$ (typically $20 \mathrm{~dB}$ over a day vs $10 \mathrm{~dB}$ over a day, respectively). During periods of high wave energy (i.e. JD 217-225), the gradient between the lower water column and near surface $B k$ decreases and becomes nearly uniform throughout the water column, especially at the peak or just after the peak high tide. The variation in the $B k$ time series observed at 2.0 mab over the fore reef was very similar to the near bed at
$0.2 \mathrm{mab} B k$ time series $\left(R^{2}=0.47\right.$; significant above the $0.1 \%$ level) but appears to be slightly more modulated by the tides than the near bed $B k$. The $B k$ in the lower portion of the water column is well correlated with $H_{s}\left(R^{2}=0.52\right.$; significant above the $0.1 \%$ level) but is poorly correlated with $X_{s}\left(R^{2}=0.06\right)$. Conversely, $B k$ near the surface at 6.0 mab demonstrates a strong inverse correlation with $X_{s}\left(R^{2}=0.34\right)$ and is positively correlated with $H_{s}\left(R^{2}=0.33\right)$. It thus appears that $B k$ near the bed and lower water column was more closely linked to $H_{s}$, while $B k$ near the surface was a function of cross-shore flows.

\subsection{Sediment accumulation on the fore reef}

Sediment collected by the rotary sediment trap on the fore reef temporally differed in grain size. The average daily collection rate, calculated by measuring the total mass of sediment collected in each bottle and dividing by the cross-sectional area of the collection funnel and the time under the collection funnel was $13.9 \pm 27.5 \mathrm{~g} / \mathrm{m}^{2} / \mathrm{d}$ (Fig. 8). The first (\#1) and last (\#9) 4.8 day collection intervals started before and ended after, respectively, the 40 days of data reported here and thus will not be addressed. The maximum accumulation rate of $31.5 \mathrm{~g} / \mathrm{m}^{2} / \mathrm{d}$ was observed in the last interval (\#8) collected entirely during the experiment. The variation in accumulation rate through time displayed a non-significant relationship with $H_{s}$ and excess shear stress. This is in contrast to the strong power-law relationship found between these parameters during the winter and spring of the same year (Bothner and Storlazzi, unpublished data).

The composition of the sediment collected by the rotary sediment trap was also dependent on grain size. The coarser fractions, sand and coarse silt, were predominantly $(100 \%$ and $75 \%$ by mass, respectively) calcareous sediment postulated to be derived from the erosion of local coral and coralline algae both on the reef flat and the fore reef. High concentrations of these coarser particles were only observed in the bottles that collected during the more energetic periods (JD 217-225, 235-238 and 252-253) when larger deep-water waves impacted Molokai's south shore. The finer 


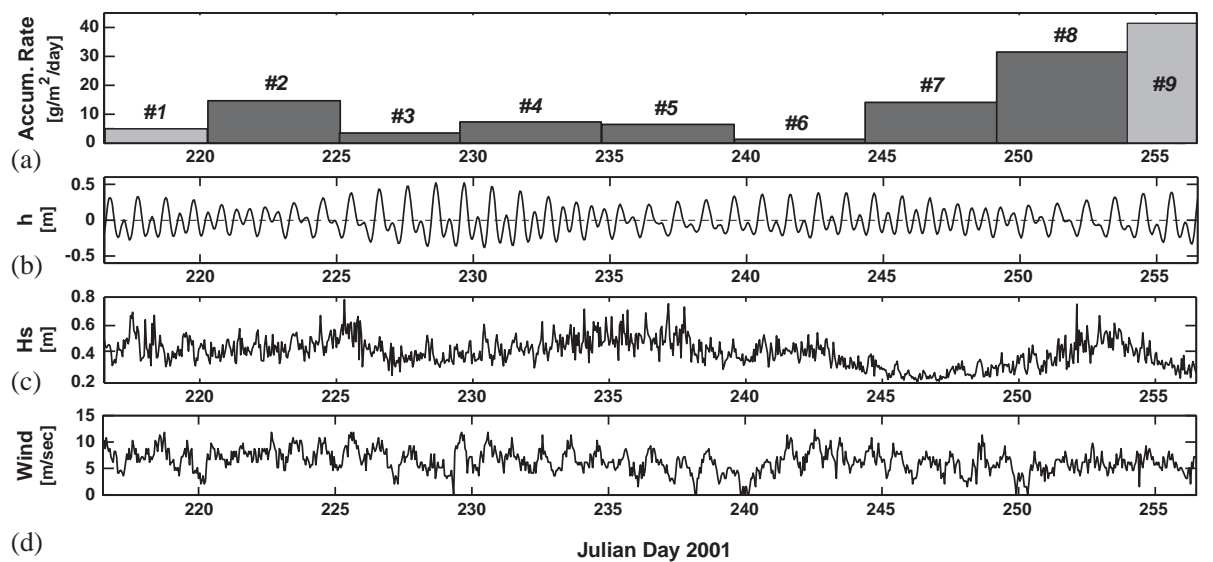

Fig. 8. Data from the rotary sediment trap on the fore reef compared to the meteorologic and oceanographic forcing during the field experiment. (a) Sediment accumulation rate from the rotary sediment trap. (b) Tidal height from the co-located wave gauge. (c) Wave height from the co-located wave gauge. (d) Wind speed from the Hoolehua Airport, Molokai. The more lightly shaded bins denote bottles that started (bottle \#1) or ended (bottle \#9) accumulating sediment outside of the 40 day experiment window and thus should not be directly compared to the forcing data presented here. The variation in accumulation rate through time displays a very loose, non-significant relationship with both $H_{s}$ and excess shear stress.

particles (fine silts and clays) were predominantly terrigenous $(67.8 \%$ by mass $)$ in origin, likely derived from the erosion of subaerial volcanic cones that make up the island. As discussed in the Methods Section, these fine-grained particles are likely under-represented in the trap due to their slow settling velocities relative to the currents speeds and wave-orbital velocities. While not quantitatively measured, qualitative observations showed that the majority of the sediment in the trap by volume was fine terrigenous sediment. The size fractionation discussed here was observed in the field during numerous surveys and instrument deployment or recovery operations over the preceding year.

\section{Discussion}

\subsection{Reef flat processes}

Water temperatures typically rose due to insolation during the day and dropped at night throughout the deployment; this rise in temperature typically coincided with the increase in Trade wind strength due to heating of the island. These daily cycles were modulated, however, by the 12.4 and $24.8 \mathrm{~h}$ tidal cycles. Water on the reef flat was typically cooler, higher in salinity and had lower suspended sediment concentration $(C)$ during low and rising tides than during high or falling tides. Net suspended sediment flux, measured as the product, $C X S$ is generally negligible to slightly onshore during the rising tide. As the tide rose, flow on the reef flat was typically onshore and the $C$ slowly increased. Kraines et al. (1998) and Tartinville and Rancher (2000) observed similar current speeds and directions relative to the reef crest over atolls and fringing reefs in similar water depths. This onshore flow was likely driven by the 5-10 cm cross-shore difference in the sea surface elevation observed between the fore reef and reef flat. Unlike the almost equal cross-reef tidal fluctuations measured by Lugo-Fernandez et al. (1998), the cross-shore water surface slope of up to $0.20 \mathrm{~m}$ vertically over $600 \mathrm{~m}$ of reef could provide a significant current forcing. The unequal amplitudes and temporal offset of peaks (phase angle $>0$ ) observed off Kamiloloa suggest shallowwater deformation, in terms of timing differences and amplitude modifications, was occurring across the reef. This was likely due to the high hydraulic roughness of the reef flat, the presence of a more or less continuous reef crest in the area and the 
limited channels in the crest. These combine to make the reef crest hydraulic choke point that would hamper rapid water exchange between the fore reef and reef flat that would counter-act the differences in sea surface elevation. Overall, the sea level differences across the reef are likely driven by not only shallow-water deformation but also windand wave-induced set-up onto the reef.

Higher suspended sediment concentrations $(C)$ were generally observed at or near high tide because sediment suspension under Trade wind and wave conditions is strongly dependent on water depth over the reef flat, as discussed by Ogston et al. (in press). Higher tides not only allow more long-period deep-water wave energy to propagate on to the reef flat and increase nearbed shear stresses but also make it possible for larger short-period depth-limited waves to be generated in situ on the reef flat, especially in the mid afternoon when the Trade winds blow the strongest. As shown in calculations made by Ogston et al. (in press), the wave orbital velocities alone are generally unable to exceed the threshold shear stresses necessary for sediment suspension but, in combination with the relatively strong current velocities observed on the shallow reef flat, can suspend the fine-grained sediment that covered the bed.

As the tide falls, the warmer, less saline (likely due to submarine groundwater discharge from the beachface as noted by Presto et al., unpublished field notes) and sediment-rich water typically started to head offshore, with the flux product $C X S$ generally being negative and relatively large in magnitude. Wave-induced breaking and set-up has also been shown through GPS drifter studies to drive a very $(<0.15 \mathrm{~m})$ thin layer of surface water onshore at over $0.1 \mathrm{~m} / \mathrm{s}$ (T. Reiss, J. Logan and C. Storlazzi, unpublished field notes), contributing to the relatively large tidally induced difference in sea level across the reef. The large sea level differences across the reef were likely perpetuated by the high hydraulic roughness of the reef, which reduced the speed of water exchange between the fore reef and reef flat and thus counteracted the pressure gradient forces. Wind- and wave-driven onshore surface flow (both at the instrument site and up-coast to the east, seeing there is a strong alongshore component of flow downwind to the west) could balance the difference between the lower velocity near-bed onshore flow during rising tides and the much greater near-bed offshore flow observed during falling tides.

\subsection{Fore reef processes}

Temperature fluctuations on the fore reef appear to be much more a function of the tidal stage rather than daily insolation, which drove temperature increases on the reef flat. Cross-shore flow $\left(X_{S}\right)$ near the bed at 0.2 mab was primarily offshore during periods with large offshore waves (Fig. 4). Similar cross-shore velocities were observed for comparable water depths over fringing reefs in the Caribbean Sea by Roberts et al. (1977, 1980) and Lugo-Fernandez (1998). This may be the result of offshore-directed near-bed flow helping to balance the wind- and wave-induced set-up onto the reef flat. Acoustic backscatter $(B k)$ generally decreased during rising and high tides and increased during falling and low tides. The strong coupling with tidal height $(h)$ implies that the increased $B k$ near the bed might be resuspended coarse bed sediment that was mobilized as wave-induced near-bed shear stresses increased as $h$ decreased. Net flux, computed as the product of burst-mean $B k X_{s}$, is primarily negative (offshore) except during rising tides when it approached zero or even became slightly positive (onshore).

Higher up in the water column over the fore reef between 2.0 and $6.0 \mathrm{mab}$ there was significant variation in $X_{s}$ over the course of a tidal cycle, with onshore flow during rising tides and offshore flow during falling tides. This phasing of flow with tidal height $(h)$ was similar to what was observed by the REEFPROBE-1 on the reef flat, both in magnitude and direction. The cross-shore flow $\left(X_{S}\right)$ higher above the bed at 2.0 and $6.0 \mathrm{mab}$ on the fore reef demonstrated much more variability than near the bed at $0.2 \mathrm{mab}$. The near zero mean offshore flow between 2.0 and $6.0 \mathrm{mab}$ would suggests that the mean near-bed offshore flow at $0.2 \mathrm{mab}$ may have been an offshore-directed and sediment-rich near-bed flow (negative $B k X_{S}$ ) 
balancing wind- and wave breaking-induced onshore surface flows.

Acoustic backscatter $(B k)$ at $z>2.0 \mathrm{~m}$ over the fore reef differed substantially from that observed just above the bed at 0.2 mab. Instead of $B k$ being generally greater at low tide as was the case near the bed, $B k$ was generally greater during high and falling tide. This increase in $B k$ during the falling tide would suggest that the increased $B k$ observed above the fore reef would likely be due to the increased suspended sediment concentrations $(C)$ observed on the reef flat during high tide being advected offshore onto the fore reef as the tide dropped. The strong correlation between $B k$ in the upper water column on the fore reef and $C$ on the reef flat further supports the conclusion that the $B k$ observed on the fore reef was related to $C$ on the reef flat and thus that $B k$ can be used as a scaled proxy for $C$ on the fore reef. A major factor supporting this theory are the differences between $B k$ at $2.0 \mathrm{mab}$ and $B k$ at $6.0 \mathrm{mab}$. Acoustic backscatter $(B k)$ at 2.0 mab tended to be almost $20 \mathrm{~dB}$ greater than the $B k$ at 6.0 mab during low tides. This makes sense, for suspended sediment concentration profile typically decreases with increased elevation above the bed. At high tide, however, the difference between of $B k$ at 2.0 and $6.0 \mathrm{mab}$ decreased to less than $5 \mathrm{~dB}$ and often to indiscernible levels (Fig. 7). This uniform $B k$ profile appears to suggest that a plume of sediment suspended on the reef flat during high tide was advected off the reef flat onto the fore reef. Strong water motions due to wave breaking and shoaling on the reef crest and upper fore reef, in conjunction with the small grain size of the material being suspended on the reef flat, likely helped to maintain the uniform vertical $B k$ (or $C$ ) profile over the fore reef during the initial drop in the tide. Eventually, however, gravitational settling broke down this uniform profile and the typical suspended sediment concentration profile developed that increases with decreasing elevation above the bed.

\subsection{Conceptual model of reef flat-fore reef coupling}

The measurements presented here suggest three main controls on cross-shore flow, sediment suspension and the resulting cross-shore flux of suspended sediment: deep-water waves, tides and daily Trade winds. Large deep-water waves are typically the dominant source of near-bed shear stress on the inner shelf of the North Pacific Ocean. Energetic waves typically impact the coast at periods $>36 \mathrm{~h}$ and impart near-bed waveorbital velocities that are often an order of magnitude greater than near-bed current speeds. These energetic waves impart the greatest shear stresses upon the fore reef during low tides when the water depth is the least, suspending the coarse carbonate sediment that makes up the fore reef's bed. When these large deep-water waves break at the reef crest, they tend to drive water up onto the reef flat, increasing water depth $(h)$ on the reef flat. These waves often suspend the fine-grained terrestrial sediment in the nearshore mud belt that is then advected off onto the fore reef by tidal and Trade wind wave-driven flows. The daily $(24.0 \mathrm{~h})$ Trade wind intensification due to insolation increases short-period deep-water Trade windwave heights off Molokai, causing increased wave breaking at the reef crest that then forces more water up onto the reef. This drives offshoredirected return flow $\left(-X_{S}\right)$ on the reef flat and over the fore reef (Fig. 9). Increased Trade wind speeds in the afternoon also generate larger in situ waves on the reef flat, increasing fine grained terrestrial sediment suspension $(C)$ on the reef flat and what appears to be its advection out over the fore reef, increasing acoustic backscatter $(B k)$. The tides, which primarily operate on $24.8 \mathrm{~h}$ (diurnal) and $12.4 \mathrm{~h}$ (semi-diurnal) periods, modulate the water depth $(h)$ and drive cross-shore flows on the reef flat and over the fore reef, with onshore flows $\left(+X_{s}\right)$ during flood tide and offshore $\left(-X_{s}\right)$ flows during ebb tide (Fig. 10). Their modulation of water depth constrains in situ development of Trade wind waves on the reef flat and the relative impact of deep-water wave-induced near-bed shear stress on the fore reef. The $0.4-0.9 \mathrm{~m}$ tidal range often more than doubles the water depth on the reef flat; this large change in water depth relative to the total water depth on the reef flat implies a large exchange of water across the reef crest that results in the cross-shore flows observed in the data collected on both on the reef flat and over the fore reef. 

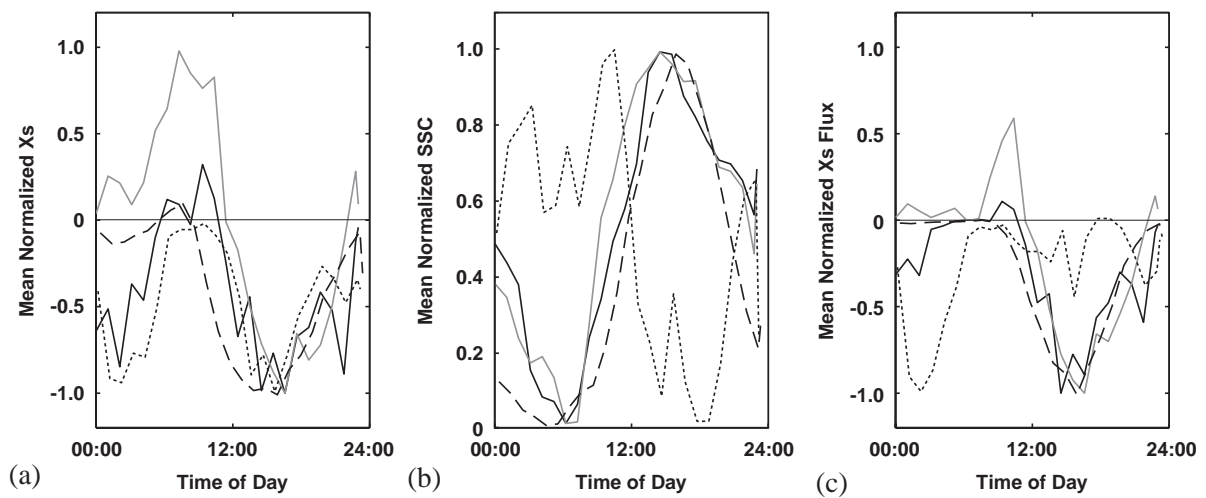

$\begin{array}{cc}-- \text { Reef flat: } 0.2 \mathrm{~m} \text { above the bed } \quad \text { Fore reef: } 2.0 \mathrm{~m} \text { above the bed } \\ \ldots \text { Fore reef: } 0.2 \mathrm{~m} \text { above the bed } & \text { Fore reef: } 6.0 \mathrm{~m} \text { above the bed }\end{array}$

-- Reef flat: $0.2 \mathrm{~m}$ above the bed $\longrightarrow$ Fore reef: $2.0 \mathrm{~m}$ above the bed
- Fore reef: $0.2 \mathrm{~m}$ above the bed
- Fore reef: $6.0 \mathrm{~m}$ above the bed

Fig. 9. Mean phasing between reef flat and fore reef hydrodynamics, sediment suspension and sediment flux on the reef flat relative to tidal height for the entire deployment. (a) Cross-shore current velocity, with positive values onshore. (b) Suspended sediment concentration. (c) Cross-shore suspended sediment flux, with positive values onshore. The tidal heights have been normalized to vary between -1 (low tide) and +1 (high tide) and mean sea level $=0$. The flow and flux data have been normalized to vary between -1 and +1 while the concentration data has been normalized to vary between 0 and +1 .
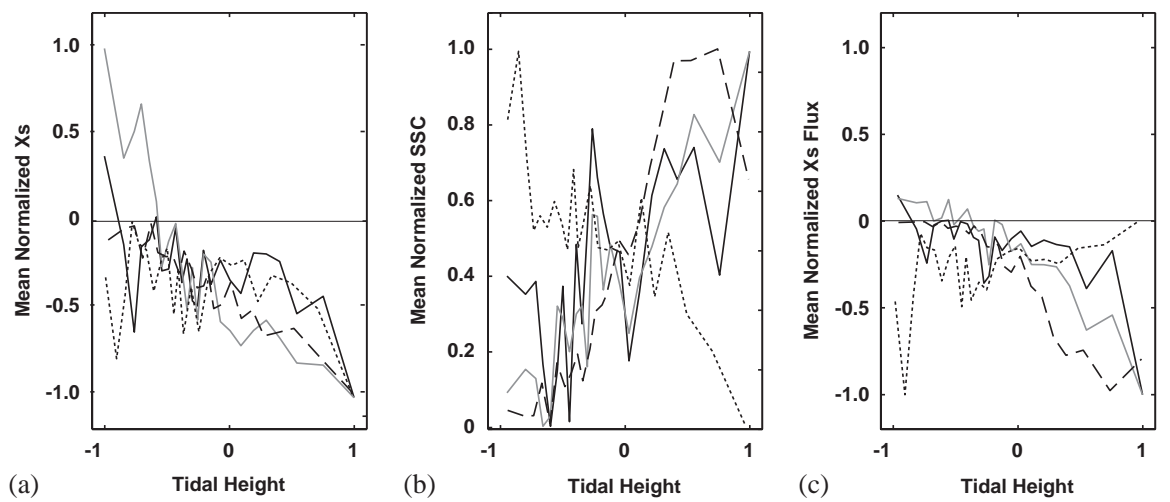

-- Reef flat: $0.2 \mathrm{~m}$ above the bed $\longrightarrow$ Fore reef: $2.0 \mathrm{~m}$ above the bed
$\ldots \ldots$ Fore reef: $0.2 \mathrm{~m}$ above the bed
Fore reef: $6.0 \mathrm{~m}$ above the bed

Fig. 10. Mean phasing between reef flat and fore reef hydrodynamics, sediment suspension and sediment flux on the reef flat relative to the time of day for the entire deployment. (a) Cross-shore current velocity, with positive values onshore. (b) Suspended sediment concentration. (c) Cross-shore suspended sediment flux, with positive values onshore. The flow and flux data have been normalized to vary between -1 and +1 while the concentration data has been normalized to vary between 0 and +1 .

These analyses, in conjunction with numerous field observations and GPS drifter studies (T. Reiss, J. Logan and C. Storlazzi, unpublished field notes) evoke the following conceptual model of water and fine-grained sediment transport across the reef. Relatively cool, clear water flows up onto the reef flat during flooding tides (Fig. 11), driven by an across-shore gradient in sea surface elevation caused by friction, shallow-water deformation and Trade wind- and wave-induced set-up. Most deep-water wave energy is dissipated due to breaking at the reef crest and thus little of it propagates onto the reef flat. Even in the presence of strong Trade winds, the shallow water depth of the reef flat at low tide does not allow large depthlimited waves to be formed in situ on the reef flat. 
(a)

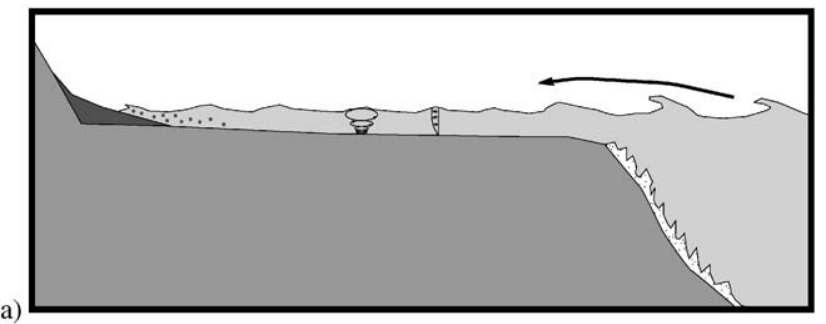

(b)

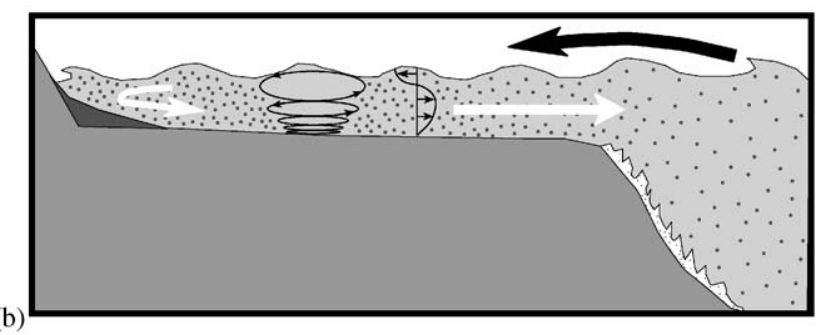

(c)

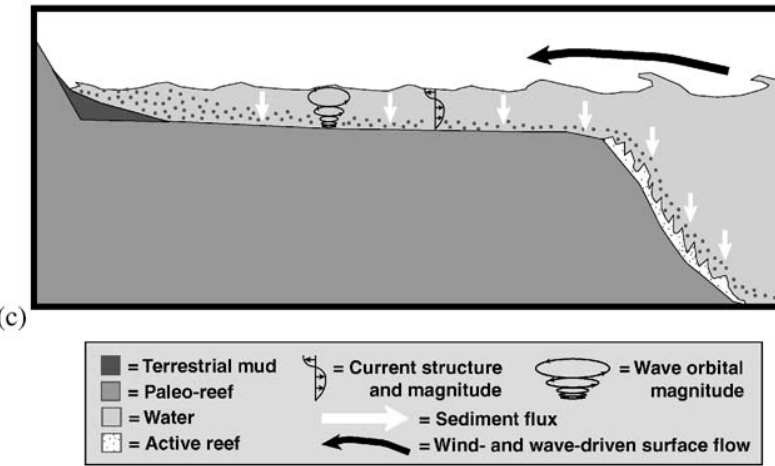

Fig. 11. Conceptual model of reef flat-fore reef coupling. (a) Low and flooding tides. At low tide very little deep-water wave energy propagates up onto the reef flat (thin black arrow) and Trade wind waves on the reef flat are small, causing uniform onshore flow throughout the water column. This combination does not generate high enough shear stresses to suspend sediment and thus water flowing onshore with the rising tide is clear. (b) High and falling tide. At high tide much more deep-water wave energy propagates up onto the reef flat (thick black arrow), more surface water is driven onto the reef flat due to wave breaking and Trade wind waves on the reef flat can grow larger due to the greater water depth over the reef flat. This combination generates high shear stresses that suspend large quantities of sediment. The near-bed return flow that balances the wave-induced set-up, in conjunction with the falling tide, drives the sediment-laden water (white arrows) out over the reef crest and onto the fore reef. (c) Slack low tide. The low tide permits less deepwater wave energy to propagate up on to the reef (thinner black arrow) and smaller Trade wind-generated waves to form on the reef flat. The lower wave energy, in conjunction with the lack of tidal currents, cause the suspended sediment to fall out of suspension, clearing the water column (white arrows). The vertical exaggeration is roughly 25:1

The smaller Trade wind driven waves on the reef flat at low tide are unable to generate large enough shear stresses to suspend large quantities of sediment. Thus, the water is relatively clear (low suspended sediment concentrations) both on the outer part of the reef flat and over the fore reef.

At high tide, more deep-water wave energy is able to propagate onto the reef flat. These waves are much longer period than those generated in situ on the reef flat and thus generate higher shear stresses for their wave height than the very short period Trade wind waves. Due to the greater water depth over the reef flat at high tide, larger Trade wind-driven waves can develop in situ on the water depth-limited reef flat than during low tide. These in situ-generated Trade wind waves, in 
combination with wind-driven currents and the greater proportion of deepwater wave energy that can propagate up onto the reef flat, increase shear stresses and thus sediment suspension on the reef flat. The deep-water waves breaking at the reef crest are also larger due to less energy being dissipated by bottom friction over the hydraulically rough fore reef due to the greater water depth. These larger deep-water waves cause increased setup of water on the reef flat, further increasing the water depth on the reef flat and enhancing the development of depth-limited waves and thus sediment suspension. As the tide ebbs, the water and associated suspended sediment on the reef flat drains off of the reef flat and is advected offshore due to the large cross-shore pressure gradient. This large gradient is established by the wind- and wave-induced set-up at high tide and is enhanced by the dropping of the tide over the fore reef first and ponding of the water on the reef flat due to the reef crest acting as a hydraulic choke point. The sediment rich water then flows out over the fore reef in a nepheloid layer that slowly settles over the fore reef as the cross-shore flow decreases when low tide is reached.

\subsection{Implications of observations to reef health}

As discussed by Rogers (1990), sediment accumulation rates of greater than $100 \mathrm{~g} / \mathrm{m}^{2} / \mathrm{d}(10 \mathrm{mg} /$ $\mathrm{cm}^{2} / \mathrm{d}$ ) are associated with fewer coral species, less live coral, and decreased net productivity. The accumulation rates discussed by Rogers (1990), however, were typically made $<0.5 \mathrm{~m}$ from bed and thus are higher than what would be seen $>1.0 \mathrm{~m}$ above the bed where the suspended sediment concentration $(C)$ profile decreases and both currents speeds and wave orbital velocities are higher, reducing trapping efficiency. If we assume a $50 \%$ reduction in trapping efficiency, in conjunction with the under-sampling of fine particles in the trap as discussed previously, then the accumulation rates observed off central Molokai's depauperate fore reef approach the values quoted by Rogers (1990) that are detrimental to reef health. Furthermore, Dodge et al. (1974) noted that in some areas that corals showed decreased growth rates when accumulation rates
$>10 \mathrm{~g} / \mathrm{m}^{2} / \mathrm{d}$, an order of magnitude lower than those presented by Rogers (1990).

Other researchers (e.g. Marszalek, 1981) suggest that prolonged turbidity and the resulting chronic decreased photosynthetically available radiation (PAR) is more detrimental to corals than shortterm accumulation of sediment. The temporal variations in suspended sediment concentration (C) observed on the reef flat and associated acoustic backscatter $(B k)$ increases in the fore reef waters implies that under typical wave and Trade wind conditions, turbidity on the fore reef increases considerably each day due to draining of sediment-rich water off the reef flat. This draining of sediment-rich water off the reef flat during high and falling tides is at a maximum when large offshore waves strike Molokai's south shore in the early afternoon when Trade wind speeds are typically the highest. Although no quantitative data on $C$ over the fore reef are presented here, the $B k$ data suggest that a substantial volume of suspended sediment spills out over the fore reef on a daily basis during the period of study. This observation is corroborated by the accumulation of fine terrestrial sediment in the rotating sediment trap; again, this accumulation is under-represented due to the fine terrigenous particle's settling velocities relative to the current speeds and wave-orbital velocities. As discussed above, this terrestrial sediment could also have been introducing nutrients and/or toxins that could adversely affect the fore reef coral ecosystem.

Another consequence of the terrestrial sediment being advected out over the fore reef is its ability to scatter and/or absorb light that is critical to the health of the photosynthetic algae housed in the corals. Yates (written communication) observed that suspended sediment concentrations approaching $10 \mathrm{mg} / 1$ would attenuate approximately $15 \%$ of the near-bed Photosynthetically Available Radiation (PAR) on Molokai's shallow $(\sim 1 \mathrm{~m})$ reef flat. Yates and Halley (2000) have shown that although suspended sediment does reduce PAR on the reef flat, the very shallow nature of the reef flat appears to allow sufficient light penetration for adequate primary productivity and reef growth. The greater depths $(4-30 \mathrm{~m})$ over the fore reef would thus 
result in a much greater reduction in PAR for the same suspended sediment concentrations than the shallow reef flat. This reduction in PAR due to suspended sediment, even if it was only a fraction of the concentrations observed on the shallow reef flat, would compound the normal logarithmic light attenuation with depth (Stoddart, 1969, Dustan, 1979) and could potentially chronically stress corals. While we do not have specific measurements of the effect of suspended sediment on light and PAR reduction, the acoustic backscatter $(B k)$ data suggest that suspended sediment being advected off the reef flat likely contributes to reduced PAR levels over the fore reef, which could compound pre-existing factors to stress the coral ecosystem.

\section{Conclusion}

Four instrument packages were deployed across the fringing coral reef off southern Molokai, Hawaii during the summer of 2001 to understand the processes governing fine-grained terrestrial sediment suspension on the shallow reef flat and its advection across the reef crest and onto the deeper fore reef. Field observations and data from bottom-mounted instrument packages made it clear that the waves underwent breaking across the reef, causing wave height to be reduced by more than $78 \%$, wave period to be reduced by more than $79 \%$ and wave power to be reduced by more than $97 \%$. The data further suggests that waves are depth limited on the reef flat. Some deep-water wave energy does propagate onto the reef flat, especially at high tide. Substantial crossshore differences $(0.10-0.20 \mathrm{~m})$ in sea surface elevation, along with wave-induced breaking drive flow across the reef crest at speeds of $0.10 \mathrm{~m} / \mathrm{s}$.

On the reef flat during low and rising tides, flow was typically onshore and little sediment was suspended. Wind wave development was limited and there was a lack of substantial deep-water wave energy able to propagate onto the reef flat during this tidal stage. At high tide, more deepwater wave energy is transmitted onto the reef flat and larger depth-limited Trade wind-driven waves formed on the reef flat, increasing sediment suspension. As the tide ebbed, the water and associated suspended sediment on the reef flat drained and was advected offshore. Observations on the fore reef showed relatively high turbidity throughout the water column during the ebb tide. Near the bed on the fore reef, sediment suspension (as approximated by acoustic backscatter measurements) appeared to be more a function of deep-water wave energy and tidal height. Higher up in the water column, suspended sediment concentrations were more linked to tidal currents, with higher concentrations occurring during offshore flow. Seeing that measured suspended sediment flux on the reef flat was offshore during high and falling tides, it is likely that the suspended sediment observed on the fore reef was being advected from its source on the shallow, muddy reef flat. It therefore appears that high suspended sediment concentrations on the deeper fore reef, where active coral growth is at a maximum, are dynamically linked to processes on the muddy, shallow reef flat.

\section{Acknowledgements}

This work was carried out as part of the USGS's Coral Reef Project as part of an effort in the US and its trust territories to better understand the health and geologic variability of coral reef systems. Andrea Ogston and Kathy Presto contributed as part of the ongoing USGS/University of Washington Cooperative Studies Program. Joshua Logan and Tom Reiss (USGS) helped during most of the boat operations, produced most of the maps we used in the field and collected most of our geospatial information, and for that we owe them much thanks. Michael Casso (USGS) and Rick Rendigs (USGS) deserve thanks, for they ran the rotary sediment trap, downloaded the data, processed the sediment samples and were just great guys to spend time with in the field. Simon Barber (USGS), Carolyn Box (USGS) and Becky Stamski (UCSC) deserve special credit for committing an enormous amount of time and effort processing the sediment samples. We would also like to thank Joe Reich, the captain of the $R / V$ Alyce $C$., who piloted and navigated 
during the coral coverage surveys, numerous dive transects and instrument deployments. Dan Hanes (USGS) and Jessica Lacy (USGS) who provided extremely constructive initial reviews of this manuscript, and for that we would like to thank them. We would also like to thank Peter Ridd, Alexis Lugo-Fernandez and the editors at Continental Shelf Research for their time and effort in helping to make this a better manuscript.

\section{References}

Acevedo, R.J., Morelock, J., Olivieri, R.A., 1989. Modification of coral reef zonation by terrigenous sediment stress. Palios 4, 92-100.

Barber, S.G., 2002. Laboratory procedures and grain size analysis of terrigenous and carbonaceous sediment of the fringing reef of Molokai, Hawaii. Thesis, San Francisco State University, San Francisco, CA, Appendix A, pp. 4-13.

Bastidas, C., Bone, D., Garcia, E.M., 1999. Sedimentation rates and metal content of sediments in a venezuelan coral reef. Marine Pollution Bulletin 38 (1), 16-24.

Birkemeier, W.A., Baron, C.F., Leffler, M.W., Hathaway, K.K., Miller, H.C., Strider, J.B., 1989. SUPERDUCK nearshore processes experiment data summary. CERC Field Research Facility. U.S. Army Corps of Engineers Miscellaneous Paper CERC-89-16.

Buddemeir, R.W., Hopley, D., 1998. Turn-ons and turn-offs: causes and mechanisms of the initiation and termination of coral reef growth. Proceedings of the Sixth International Coral Reef Congress, pp. 253-261.

Calhoun, R.S., Field, M.E., 2002. Beach and reef-flat sediments along the south shore of Molokai, Hawaii. Proc. Carbonate Beaches 2000, American Society of Civil Engineers, pp. 163-171.

Clague, D.A., Dalrymple, G.B., 1989. Tectonics, geochronology, and origin of the Hawaiian-Emperor volcanic chain. In: E.L. Winterer, D.M. Hussong, R.W. Decker (Eds.), The Eastern Pacific Ocean and Hawaii, pp. 188-217. In: The Geology of North Amercia, vol. N, Geological Society of America, Boulder, Colorado.

Dickson, K.L, Maki, A.W., Brungs, W.A., 1987. Fate and Effects of Sediment-bound Chemicals in Aquatic Systems. Pergamon Press, New York.

Dodge, R.E., Vaisnys, J.R., 1977. Coral populations and growth pattern: responses to sedimentation and turbidity associated with dredging. Journal of Marine Research 35, 715-730.

Dodge, R.E., Aller, R.C., Thompson, J., 1974. Coral growth related to suspension of bottom sediments. Nature 247, 574-577.

Dustan, P., 1979. Distribution of zooxanthellae and photosynthetic chloroplast pigments of the reef-building coral
Monastera annularis, Ellis and Solander, in relation to depth on a West Indian reef. Bulletin of Marine Science 29, 79-95.

Edmunds, P.J., Spencer-Davies, P., 1989. An energy budget for Porites porites (scleractinia), growing in a stressed environment. Coral Reefs 8, 37-43.

Fletcher, C.H., Richmond, B.M., Grossman, E.E., 2002. Atlas of Natural Hazards in the Hawaiian Coastal Zone. USGS Geologic Investigations Series I-2716.

Fortes, M., 2000. The effects of siltation on tropical coastal ecosystems. In: Wolanski, E. (Ed.), Oceanographic Processes of Coral Reefs. CRC Press, Boca Raton, pp. 93-112.

Holdaway, G.P., Thorne, P.D., Flatt, D., Jones, S.E., Prndle, D., 1999. Comparison between ADCP and transmissometer measurements of suspended sediment concentration. Continental Shelf Research 19, 421-441.

Hubbard, D.K., Scature, D., 1985. Growth rates of seven species of scleractinian corals from Cane Bay and Salt River, St. Croix, USVI. Bulletin of Marine Science 32, 890-908.

Jokiel, P.L., Brown, E.K., Friedlander, A., Rodgers, S.K., Smith, W.R., 2001. Hawaii Coral Reef Initiative Coral Reef Assessment and Monitoring Program (CRAMP) Final Report 1999-2000. University of Hawaii.

Kraines, S.B., Yanagi, T., Isobe, M., Komiyama, H., 1998. Wind-wave driven circulation on the coral reef at Bora Bay, Miyako Island. Coral Reefs 17, 133-143.

Larcombe, P., Ridd, P.V., Prytz, A., Wilson, B., 1995. Factors controlling suspended sediment on inner-shelf coral reefs, Townsville, Australia. Coral Reefs 14, 163-171.

Larcombe, P., Woolfe, K.J., Purdon, R.G., 1996. Great Barrier Reef: Terrigneous Sediment Flux and Human Impacts. CRC Reef Research Centre, Current Research, Townsville.

Lugo-Fernandez, A., Roberts, H.H., Wiseman, W.J., Carter, B.L., 1998. Water level and currents of tidal and infragravity periods at Tague Reef, St. Croix (USVI). Coral Reefs 17, 343-349.

Marszalek, D.S., 1981. Impact of dredging on a subtropical reef community: Southeastern Florida, USA. Proceedings of the fourth International Coral Reef Congress, pp. 147-153.

Moberly, R.M., Chaimberlin, T., 1964. Hawaiian Beach Systems, University of Hawaii.

Nelson, R.C., Lesleighter, E.J., 1985. Breaker height attenuation over platform coral reefs. Australian Conference on Coastal and Ocean Engineering, Christchurch, NZ. Vol. 2, pp. 9-16.

Ogston, A.S., Storlazzi, C.D., Field, M.E., Presto, M.K., in press. Currents, suspended sediment transport on a shallow reef flat: South-central Molokai, Hawaii. Coral Reefs.

Osborne, P.D., Vincent, C.E., Greenwood, B., 1994. Measurement of suspended sand concentrations in the nearshore: field comparison between optical and acoustic backscatter sensors. Continental Shelf Research 14 (2,3), 159-174.

Reichel, G., Nachtnebel, H.P., 1994. Suspended sediment monitoring in a fluvial environment: advantages and limitations of applying an acoustic Doppler current profiler. Water Research 28 (4), 751-761. 
Roberts, H.H., Murray, S.P., Suhayda, J.N., 1977, Physical processes in a fore-reef shelf environment. Proceedings of the Third International Coral Reef Symposium, Vol. 2, pp. 507-515.

Roberts, H.H., Murray, S.P., Suhayda, J.N., 1980. Physical processes in a fringing reef system. Journal of Marine Research 33, 233-260.

Rogers, C.S., 1979. The effect of shading on coral reef structure and function. Journal of Experimental Marine Biology and Ecology 41, 269-288.

Rogers, C.S., 1990. Responses of coral reefs and reef organisms to sedimentation. Marine Ecology Progress Series 62, 185-202.

Sontek, 1997. Sontek Doppler Current Meters-Using Signal Strength Data to Monitor Suspended Sediment Concentration. Application Note, Sontek, San Diego.

Souter, E., Campbell, P.G., Ribeyre, F., Boudou, A., 1993. Use of partial extractions to study mercury partitioning on natural sediment particles - a coutionary note. International Journal of Environmental Analytical Chemistry 54, $57-68$.

State of Hawaii, 2001. Map of median annual rainfall in millimeters and inches: Molokai, Hawaii. Department of Land and Natural Resources, online, dataset, http:// www.state.hi.us/dbedt/gis.
Stoddart, D.R., 1969. Ecology and morphology of recent coral reefs. Biology Review 44, 433-498.

Tartinville, B., Rancher, J., 2000. Wave-induced flow over Mururoa Atoll Reef. Journal of Coastal Research 16 (3), 776-781.

Thorne, P.D., Hanes, D.M., 2002. A review of acosutic measurements of small-scale sediment processes. Continental Shelf Research 22, 603-632.

Thorne, P.D., Vincent, C.E., Hardcastle, P.J., Rehman, S., Pearson, N., 1991. Measuring suspended sediment concentrations using acoustic backscatter devices. Marine Geology 98, 7-16.

van Katwijk, M.M., Meier, N.F., van Loon, R., van Hove, E.M., Giesen, W.B., van der Velde, G., den Hartog, C., 1993. Sabaki River sediment load and coral stress: correlation between sediments and condition of the MalindiWatamu reefs in Kenya (Indian Ocean). Marine Biology 117, 675-683.

Wright, L.D., Kim, S.C., Friedrichs, C.T., 1999. Across-shelf variations in bed roughness, bed stress, and sediment suspension on the northern california shelf. Marine Geology 154, 99-115.

Yates, K., Halley, R.H., 2000. Reef production in a shallow, turbid environment. Abstract volume, Ninth International Coral Reef Symposium, Bali, pp. 66. 